\title{
Assessing relative sensitivity of marine and freshwater bivalves following exposure to copper: Application of classical and novel genotoxicological biomarkers
}

\author{
Jha, Awadhesh
}

http://hdl.handle.net/10026.1/13594

10.1016/j.mrgentox.2019.01.008

Mutation Research - Genetic Toxicology and Environmental Mutagenesis

Elsevier

All content in PEARL is protected by copyright law. Author manuscripts are made available in accordance with publisher policies. Please cite only the published version using the details provided on the item record or document. In the absence of an open licence (e.g. Creative Commons), permissions for further reuse of content should be sought from the publisher or author. 
Assessing relative sensitivity of marine and freshwater bivalves following exposure to copper: Application of classical and novel genotoxicological biomarkers

Emily L. Vernon, Awadhesh N. Jha*

${ }^{a}$ School of Biological and Marine Sciences

University of Plymouth, Plymouth, PL4 8AA, UK

*Correspondence: a.jha@plymouth.ac.uk 


\section{Abstract}

Determination of relative sensitivity of biota following exposures to contaminants including metals is important for environmental protection. Copper $(\mathrm{Cu})$, although biologically essential can be highly toxic to biota if present at higher concentrations in the natural environment. Given its ubiquitous presence within coastal and inland water bodies, we compared Cu-induced genotoxicity in two ecologically important mussel species, the freshwater Dreissena polymorpha (DP) and marine Mytilus galloprovincialis (MG), along with its tissue specific accumulation. Novel biomarker in terms of induction of gamma $\mathrm{H} 2 \mathrm{AX}(\mathrm{Y}-\mathrm{H} 2 \mathrm{AX})$ foci, along with comet assay and induction of micronuclei (MN) were used to determine DNA damage response (DDR) in these two species following exposure to a range of $\mathrm{Cu}$ concentrations $\left(18,32,56 \mu \mathrm{g} \mathrm{L}^{-1}\right)$ for 10 days. Concentration-dependent increases in $\mathrm{Cu}$ concentration in gill tissue, as determined by Inductively Coupled Plasma Mass Spectrometry (ICP-MS), were paralleled by a greater degree of genotoxicity. An induction of $\mathrm{y}-\mathrm{H} 2 \mathrm{AX}$ foci was present in all $\mathrm{Cu}$ exposure concentrations, proving this technique to be a sensitive and suitable biomarker of genotoxicity in bivalves. The multibiomarker approach adopted here suggests firstly that in parallel with MG, which is widely used to assess the health of marine and coastal environment, DP is also suitable representative of inland water bodies, and that there is a similar mechanism of action for the induction of genotoxicity between the two species, following exposure to $\mathrm{Cu}$. Secondly, for genotoxicity assessment a battery of responses could simultaneously be assessed in these two bivalve species. Finally, for adequate protection of the environment it is vital to adopt a multi-biomarker, multi-species approach to determine adverse biological effects to gain a holistic understanding of the real threat posed by contaminants to hydrosphere.

Keywords: Metals; Bivalve; DNA damage; $y-H 2 A X$; Bioaccumulation; Genotoxicity

Abbreviations: $\mu \mathrm{g}$, Microgram; $\mu \mathrm{M}$, Micromole; $\mathrm{y}-\mathrm{H} 2 \mathrm{AX}$, Gamma-H2AX; AM, Adductor muscle; Cu, Copper; DAPI, 4',6-diamidino-2-phenylindole, dihydrochloride; DDR, DNA damage response; DG, Digestive gland; DO, Dissolved oxygen; DOC, Dissolved organic carbon; DP, Dreissena polymorpha; DSB, Double strand break; $\mathrm{H}_{2} \mathrm{O}_{2}$, Hydrogen peroxide; ICP-MS, Inductively coupled plasma mass spectrometry; LMA, Low melting point agarose; MG, Mytilus galloprovincialis; MN, Micronuclei; NMA, Normal melting point agarose; OST, Other soft tissue; ROS, Reactive oxygen species. 


\section{Introduction}

Identification of most sensitive natural species following exposure to anthropogenic contaminants is important from an environmental protection point of view [1-4]. In recent years there has been growing regulatory and scientific concerns for those contaminants which have the potential to exert carcinogenic, mutagenic and endocrine disrupting effects [5]. In this context, it is also emerging that contaminants could simultaneously induce their toxicity in a variety of ways, i.e. the same contaminant could induce carcinogenic, mutagenic, immunotoxic and endocrine disrupting effects [2].

Metals are an important group of ubiquitous contaminants to which biota are exposed in different habitats and ecological niches $[4,6]$. Exposure to metals can induce a variety of detrimental biological effects via a range of mechanisms, including through the generation of reactive oxygen species (ROS). In addition to damage to cellular components such as lipids and proteins, DNA damage (either directly or through generation of ROS), inhibition of DNA repair capacity and disruption of cell cycle control are of particular concern [5-12]. Although various metals are essential for biological processes, copper $(\mathrm{Cu})$ in particular being important for growth, metabolism and enzymatic activities [13-16], they can be highly toxic to organisms including bivalves at higher concentrations $[6,17]$. Cu has been the focus of extensive research as a widespread contaminant present in coastal and inland water bodies globally and is considered to be of greater environmental concern compared to other contaminants such as pharmaceuticals [18-19]. Total dissolved $\mathrm{Cu}$ in contaminated environments have been found to reach concentrations of $689 \mu \mathrm{g} \mathrm{L}^{-1}$ [20], with permitted levels in England and Wales ranging from $1-28 \mu \mathrm{g} \mathrm{L}^{-1}$ in freshwater (dependant on water hardness), and $5 \mathrm{\mu g} \mathrm{L}^{-1}$ in seawater [21].

The link between metal (in particular $\mathrm{Cu}$ ) exposure and genotoxicity as determined by induction of micronuclei (MN) and DNA strand breaks (as determined by comet assay), has been well documented in a range of aquatic species, including bivalves [6,17, 22-33]. Induction of DNA strand breaks has been noted at environmentally relevant $\mathrm{Cu}$ concentrations in several bivalve species, including Mytilus spp. (18-56 $\left.\mu \mathrm{g} \mathrm{L}^{-1}\right)$, Perna perna (37.5-50 $\left.\mathrm{g} \mathrm{L} \mathrm{L}^{-1}\right)$, Limnoperna fortunei (375-750 $\mathrm{gg} \mathrm{L}^{-1}$ ) and Crassostrea gigas (embryos, $1-20 \mu \mathrm{g} \mathrm{L}^{-1}$ ) $[6,17,25,27,30,34]$.

Species-specific differences in bioaccumulation and resultant biological response following exposure to environmental contaminants have been reported for different marine bivalves $[4,32,35-36]$. Despite the fact that (a) freshwater and marine bivalves are comparable in 
their external and internal anatomical structures [37] and (b) contaminants including metals are highly relevant to both marine and freshwater environments, there have been no attempts to compare the relative bioaccumulation and biological responses in these ecologically relevant organisms. The marine, Mytilus galloprovincialis (MG) and freshwater mussel, Dreissena polymorpha (DP) were chosen for this study as ecologically relevant representatives of both coastal and inland water bodies [37-39]. As sessile, filter feeding organisms, both species are used extensively in monitoring programmes and in toxicological research as accurate bioindicators of their environmental surroundings [40]. The physiology, anatomy and ecology of MG and DP is well understood and their effectiveness within ecotoxicological studies well documented [39]. Bivalves have developed defence and repair mechanisms to compensate for biological damage induced by metal exposures, the key players being antioxidant defence systems, detoxification and sequestration capacity and induction of multixenobiotic resistance proteins (MXR) [41-43]. As noted by Manduzio et al. [42], Al-Subiai et al. [17] and Brooks et al. [32], antioxidant enzymes (e.g. SOD, catalase, GSH) protect cells against biological perturbation (i.e. oxidative damage) by maintaining ROS at non-damaging levels. While the effects of Cu on aquatic organisms are well documented, the relative sensitivity of marine and freshwater bivalves in terms of genotoxic damage, along with defence and repair capacity is yet to be fully explored. As suggested by various authors the use of two (or more) species should be a considered as more robust, realistic approach for ecotoxicological studies [3, 4, 44-46].

The extent of damage in individuals evident at higher levels of biological organisation, subsequent to DNA strand breaks (SBs) is dependent on a range of factors including exposure period, contaminant concentrations, rate of uptake, metabolism, accumulation and the efficiency of repair mechanisms [2]. In recent years, immunostaining techniques such as induction of $\mathrm{Y}-\mathrm{H} 2 \mathrm{AX}$ foci and 53BP1 have been utilised as sensitive markers of DNA double strand breaks (DSBs) [47-48]. $\mathrm{Y}-\mathrm{H} 2 \mathrm{AX}$ plays a key role in DNA damage signalling and repair, along with activation of cell-cycle checkpoints and apoptosis [49]. It is the first step in recruiting and localizing proteins to sites of DSBs formation. Foci are taken as a measure of DNA repair, representing DSBs in a 1:1 manner [50]. The genotoxicity of various contaminants (e.g. metals, nanoparticles, insecticides and radionuclides) using induction of $\mathrm{Y}-\mathrm{H} 2 \mathrm{AX}$ foci as a biomarker has been displayed in zebrafish (Danio rerio) derived ZF4 cells, adult zebrafish liver tissue and retina, and fathead minnow (Pimephales promelas) juveniles [51-55]. Concentration-dependent DNA damage in ZF4 cells was evident following aluminium (10-100 $\mu \mathrm{M})$ and cadmium (1- $100 \mu \mathrm{M})$ exposures [53]. $\mathrm{V}^{-}$ 
H2AX foci induction followed a similar trend, where number of foci per cell increased with aluminium or cadmium concentration up to $30 \mu \mathrm{M}$, and then decreased in 50-100 $\mu \mathrm{M}$ treatments [53]. Such findings aid to our limited knowledge of DSB-repair mechanisms subsequent to exposure to environmentally relevant contaminants in non-mammalian models. In spite of usefulness of this assay, particularly when validated alongside classical genotoxicity assays (i.e. comet or MN assays), this highly sensitive approach is yet to be applied in aquatic invertebrates.

In light of the above information, following exposure to a range of $\mathrm{Cu}$, the objectives of this study were (a) to investigate the relative tissue specific accumulation of $\mathrm{Cu}$ in both bivalve species, (b) to establish a concentration-response curve for genotoxic responses in the adult life stages of the species, (c) to determine relative sensitivity between the two species for genotoxic responses using a range of genotoxicity parameters (i.e. induction of $\mathrm{MN}$, Comet and $\mathrm{y}-\mathrm{H} 2 \mathrm{AX}$ foci), (d) to correlate the nominal $\mathrm{Cu}$ concentrations in water with bioaccumulation and observed genotoxic responses and (e) to determine potential correlations between different genotoxicity parameters studied. With regards to species variation, we hypothesised firstly that little disparity in genotoxic response will be evident. Secondly, with increased DNA damage (DNA strand breaks and MN formation), a greater induction of $\mathrm{y}-\mathrm{H} 2 \mathrm{AX}$ foci will be evident.

\section{Materials and methods}

\subsubsection{Chemicals and suppliers}

All chemicals and reagents were purchased from Fisher Scientific UK, Anachem Ltd. UK, Sigma-Aldrich Ltd. UK, VWR International Ltd USA or Greiner Bio-One Ltd UK, unless stated otherwise. Product details are mentioned in text as appropriate.

\subsubsection{Mussel exposure conditions}

Four 10-day Cu exposure experiments were performed between April 2016 and December 2017, the first two to determine genotoxic responses and the latter for tissue specific $\mathrm{Cu}$ accumulation measurements. Adult MG (shell length $44.5 \pm 6.5 \mathrm{~mm}$ ) and DP (shell length $26.7 \pm 4.31 \mathrm{~mm}$ ) were collected from Trebarwith strand (as in Dallas et al. [4-5]) and Bude, Cornwall, UK (50.828059, -4.549053), respectively (Vernon et al. [37]). DP was maintained in an artificial river water solution (2M CaCl2.2H20, $8 \mathrm{mM} \mathrm{MgSO} 4.7 \mathrm{H} 2 \mathrm{O}, 40 \mathrm{mM}, 5 \mathrm{mM}$ KNO3, 0.7 M NaHCO3), MG in filtered (<10 $\mu \mathrm{M})$, aerated natural seawater. Mussels were 
fed a solution of Isochrysis galbana algae (MG; Reed Mariculture, Campbell, CA, USA) or dried Chlorella powder, two hours prior to water changes and were kept at a 12:12 photoperiod at $15^{\circ} \mathrm{C}$ as described in earlier studies from our laboratory [5,37].

Exposures of bivalves to $\mathrm{Cu}$ were staggered by one week for ease of analysis and logistical reasons. Subsequent to a two-week depuration period after collection, individual mussels were transferred into twelve acid washed glass beakers in triplicate (i.e. 1.7 mussels $\mathrm{L}^{-1}$ ), containing $1.8 \mathrm{~L}^{-1}$ of water and aerated $[5,56]$. Individuals were then acclimatised for $48 \mathrm{~h}$ prior to exposure. Beakers were labelled and assigned to one of the four treatment groups: 0 (control), 18, 32 and $56 \mu \mathrm{g} \mathrm{L}^{-1} \mathrm{Cu}$ (as CuSO4.5H2O, 99\% purity), there were three replicates per treatment (Fig. 1). $\mathrm{Cu}$ concentrations were selected in accordance to previous work from our laboratory and in line with environmental realistic values [17].

Experiment 1 (EXP1): Determination of genotoxic responses

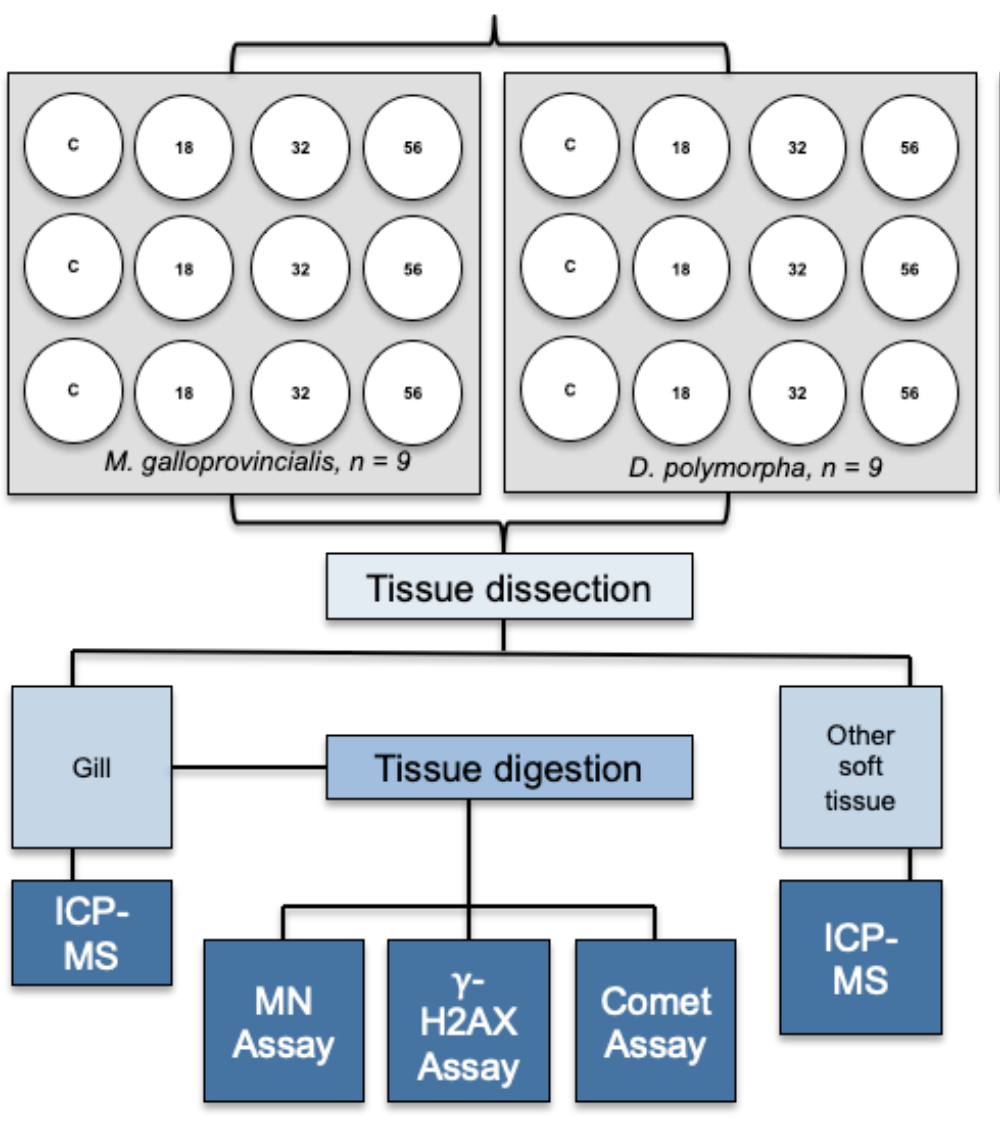

Experiment 2 (EXP2): Determination of bioaccumulation of $\mathrm{Cu}$
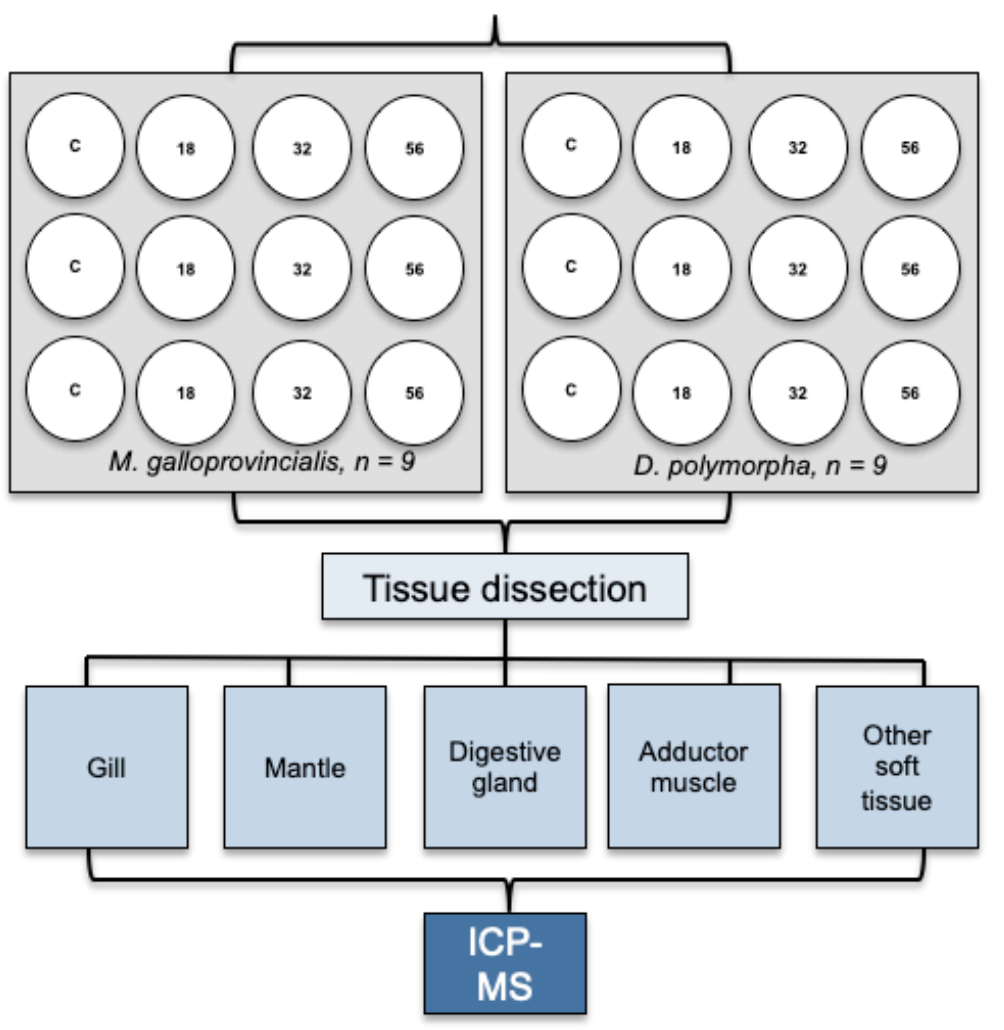

Figure 1. Overall experimental design: Experiment 1 (EXP1): Determination of Genotoxic responses; Experiment 2 (EXP2): Determination of bioaccumulation of copper $(\mathrm{Cu})$. 
Water changes were performed every alternate day with the appropriate $\mathrm{Cu}$ added to meet desired concentration. Due to the invasive nature of DP [57-58], all wastewater was spiked with salt $\left(50 \mathrm{~g} \mathrm{~L}^{-1}, \mathrm{NaCl}\right)$ before disposal as to prevent infestation and dispersal. Water samples were taken $1 \mathrm{~h}$ after each water change and processed for determination of $\mathrm{Cu}$ concentrations as described in section 2.2.2. Water quality parameters were measured daily, and before and after water changes, as outlined on table 1.

Table 1. Water quality parameters $(\mathrm{pH}$, temperature, salinity and dissolved oxygen [DO], each parameter measured daily $[n=10])$ and copper concentrations in water $\left(\mu \mathrm{g} \mathrm{L}^{-1}, n=6\right)$. Data are presented as mean \pm standard deviation (SD).

EXP 1: Genotoxicity

EXP 2: Bioaccumulation

\begin{tabular}{ccccc} 
Water parameters & M.galloprovincialis & D.polymorpha & M.galloprovincialis & D.polymorpha \\
\cline { 2 - 5 } $\mathbf{p H}$ & $8 \pm 0.11$ & $8 \pm 0.17$ & $8.1 \pm 0.06$ & $8.1 \pm 0.06$ \\
Temp ( $\left.{ }^{\circ} \mathbf{C}\right)$ & $15.4 \pm 1.22$ & $14.8 \pm 0.28$ & $15.0 \pm 0.24$ & $14.8 \pm 0.32$ \\
Salinity & $33.2 \pm 0.32$ & $0.3 \pm 0.01$ & $33.1 \pm 0.07$ & $0.3 \pm 0.01$ \\
DO (\%) & $96.5 \pm 2.47$ & $98.8 \pm 0.57$ & $99.0 \pm 0.64$ & $99.0 \pm 0.72$ \\
\hline Copper water & & & \\
conc. $\left(\boldsymbol{\mu g ~ L}{ }^{-1}\right)$ & & & & \\
\hline Control & $0.1 \pm 0$ & $3.1 \pm 0.24$ & $7.3 \pm 0.38$ & $3.6 \pm 0.43$ \\
$\mathbf{1 8}\left(\boldsymbol{\mu \text { L} ^ { - 1 } )}\right.$ & $12.5 \pm 1.49$ & $14.8 \pm 2.82$ & $20.2 \pm 0.74$ & $19.1 \pm 2.9$ \\
$\mathbf{3 2}\left(\boldsymbol{\mu \text { L} ^ { - 1 } )}\right.$ & $29 \pm 2.87$ & $25.2 \pm 1.82$ & $30 \pm 1.03$ & $31 \pm 5.41$ \\
$\mathbf{5 6}\left(\boldsymbol{\mu \text { L } ^ { - 1 } )}\right.$ & $51.6 \pm 6.23$ & $49.8 \pm 3.96$ & $47.5 \pm 2$ & $51.8 \pm 10.06$ \\
\hline
\end{tabular}

\subsection{Determination of $\mathrm{Cu}$ concentration in soft tissues and in water samples}

\subsubsection{Copper $(\mathrm{Cu})$ analysis in tissues using Inductively Coupled Plasma Mass Spectrometry (ICP-MS)}

Cu determination in tissue samples (i.e. gill, mantle, digestive gland, adductor muscle and 'other' soft tissue) and water was carried out using inductively coupled plasma mass spectrometry (ICP-MS) as described before in publications from our laboratory $[5,17,59]$. Prior to use, all equipment was acid washed (2\% nitric acid, Fisher). Subsequent to dissection, tissue samples were transferred to pre-weighed tubes (15 $\mathrm{mL}$ falcon tube, Fisher) and incubated $\left(60^{\circ} \mathrm{C},>48 \mathrm{~h}\right)$, until a constant dry weight was noted. Tubes were re-weighed and recorded for dry weight. To digest, $1 \mathrm{~mL}$ concentrated nitric acid (N/2272/PB17, Fisher) was added to each sample. As procedural blanks, 6 tubes were tested alongside containing $1 \mathrm{~mL}$ nitric acid, along with a certified reference material 
(TORT-2, lobster hepatopancreas). Samples were boiled for $2 \mathrm{~h}$ (water bath, $80{ }^{\circ} \mathrm{C}$ ), or until tissue was fully digested. Once cool, digests were diluted with $4 \mathrm{~mL}$ Milli-Q water and stored at room temperature.

\subsubsection{Determination of $\mathrm{Cu}$ in water samples using ICP-MS}

To determine Cu concentrations in water, samples taken on days 1, 5 and 9 (in duplication, $n=6$ ) were spiked with $50 \mu \mathrm{L}$ hydrochloric acid immediately after extraction and stored at room temperature until analysis. As described in Dallas et al. [5], indium (115-In) and iridium (193-Ir) were used as internal standards for both tissue and water samples. Appropriate $\mathrm{Cu}$ standards were made to calibrate the instrument before and during analysis of samples [17]. Using appropriate parameters $\left({ }^{63} \mathrm{Cu}\right.$ and $\left.{ }^{65} \mathrm{Cu}\right)$, standards and samples were run using an X Series II ICP-MS (Plasma Quad PQ2 Turbo, Thermo Elemental, Winsford, UK) with PQ Vision 4.1.2 software. Procedural blanks were run every 10 samples.

\subsection{Sampling procedures}

To determine genotoxicity (EXP1) gill tissue was extracted and stored as followed until use: $1 / 2$ gill stored on ice for digestion, $1 / 2$ gill stored in pre-weighed tube, placed in $60^{\circ} \mathrm{C}$ incubator for subsequent ICP-MS determination of $\mathrm{Cu}$ content (section 2.2). For $\mathrm{Cu}$ accumulation (EXP2) tissue was dissected into gill, mantle, digestive gland, adductor muscle and other soft tissue and processed for ICP-MS as described in section 2.2.

\subsection{Biological assays}

\subsubsection{Isolation of gill cells for genotoxicity assays}

The procedure to obtain gill cells for genotoxicity assays was adopted from previous studies [60]. Briefly, $1 \mathrm{~mL}$ dispase II solution (1.6 mg dispase powder per $1 \mathrm{ml}$ of HBSS, Sigma) was added per glass vial (20 mL, Fisherbrand ${ }^{\mathrm{TM}}$ Borosilicate Glass). This was transferred into a pre heated $\left(35^{\circ} \mathrm{C}\right)$ water bath for $5 \mathrm{~min}$ prior to use. Tissue was transferred to vials for $30 \mathrm{~min}\left(37^{\circ} \mathrm{C}\right)$; shaken every $10 \mathrm{~min}$. Following incubation, cell suspension was centrifuged (1200 rpm, $5 \mathrm{~min}$ ). Supernatant was then used in subsequent assays, providing cell viability, checked using the Trypan Blue exclusion dye assay [61], was $<90 \%$ across all treatments (data not included).

\subsubsection{Comet assay to determine DNA strand breaks}


Determination of DNA strand breaks using the single cell gel electrophoresis or the comet assay was conducted as described elsewhere in detail [62]. Prior to in vivo exposure of mussels to $\mathrm{Cu}$, the comet assay was validated using isolated gill cells using a range of concentrations of hydrogen peroxide $\left(\mathrm{H}_{2} \mathrm{O}_{2}, 100 \mu \mathrm{L}, 0,5\right.$ or $500 \mu \mathrm{M}$ in PBS, $\left.1 \mathrm{~h}\right)$ as a reference agent, as described elsewhere [5]. Briefly, cell suspension of gill cells (as described in 2.4.1, $150 \mu \mathrm{L}$ ) was used immediately for the comet assay. A cell-agarose suspension (1\% LMA, Sigma) was pipetted in duplicate, onto a pre-coated (1\% NMA in TAE) slide. After setting in the fridge $(1 \mathrm{~h})$, slides were placed in a chilled lysis buffer $(1 \mathrm{~h}$, $4{ }^{\circ} \mathrm{C}$ ). Following lysis, cells were given a $20 \mathrm{~min}$ DNA denaturation in electrophoresis buffer ( $0.3 \mathrm{M} \mathrm{NaOH}$ and $1 \mathrm{mM}$ EDTA, at $\mathrm{pH} 13)$ and then electrophoresis for $25 \mathrm{~min}$ at 21 $\mathrm{V}$ and $620 \mathrm{~mA}$. Slides were placed in a neutralisation buffer (0.4 M Tris Base, Sigma) for 5 min and then chilled distilled water for another 5 . Cells were stained with ethidium bromide (20 $\mu \mathrm{L}$ of 20,000 $\mu \mathrm{g} \mathrm{L}^{-1}$ ) and scored using an epifluorescent microscope (DMR; Leica Microsystems, Milton Keynes, UK). 100 cells per slide (50 cells per microgel) were quantified using the Comet IV imaging software (Perceptive Imaging, Bury St Edmunds, UK) software. The software provides results for different parameters, \% Tail DNA was considered the most reliable to present the results [63].

\subsubsection{Analysis of micronuclei (MN) induction}

The procedure to prepare slides for the analysis of micronuclei (MN) was adopted as described elsewhere in detail $[28,5]$, with minor modifications. Cell suspension $(50 \mu \mathrm{L})$ was smeared onto a coded slide $\left(1 \mathrm{~h}, 4^{\circ} \mathrm{C}\right)$ and were chilled to allow cells to adhere. For fixation, ice-cold carnoys solution ( $1 \mathrm{~mL}, 75 \%$ methanol, $25 \%$ glacial acetic acid) was gently pipetted onto slide and left for $20 \mathrm{~min}$. Fixative was carefully tipped off and slides allowed to dry overnight (room temp). To score, slides were stained with $20 \mu \mathrm{L}$ ethidium bromide $\left(20 \mu \mathrm{L}\right.$ of $\left.20,000 \mu \mathrm{g} \mathrm{L}^{-1}\right)$. 500 cells were scored per slide using a fluorescent microscope (as in section 2.4.2), slides were scored at random to prevent bias. Micronuclei classification was in accordance to Venier et al. [74] and Bolognesi and Fenech [28]. Results are reported as mean MN per 1000 cells, in keeping with other data from our research group [5].

\subsubsection{Induction of $\mathrm{Y}-\mathrm{H} 2 \mathrm{AX}$ foci}

Phosphorylation of the histone protein H2AX is indicative of DNA DSBs [65]. Being highly conserved between species [66] we were able to utilise antibodies from differing species to measure $\mathrm{y}-\mathrm{H} 2 \mathrm{AX}$ foci induction in marine and freshwater bivalves [67]. Prior to $\mathrm{Cu}$ 
exposure, $\mathrm{Y}-\mathrm{H} 2 \mathrm{AX}$ response was optimised and validated under in vitro conditions in numerous cells, including haemocytes, gill and digestive gland cells of both the bivalve species using standardized techniques on human cells in our laboratory conditions $[48,68]$. Optimisation of the gamma-H2AX assay in gill cells was performed using a range of concentrations of hydrogen peroxide $\left(\mathrm{H}_{2} \mathrm{O}_{2}, 100 \mu \mathrm{L}, 0,5,50\right.$ or $500 \mu \mathrm{M}$ in PBS, $\left.1 \mathrm{~h}\right)$ as a reference agent [5,69]. Briefly, gill tissue was digested as in section 2.4.1, and pooled to reduce inter-individual variability. Aliquots $(150 \mu \mathrm{L})$ of cells were transferred into microcentrifuge tubes and spun $\left(775 \mathrm{~g}, 2 \mathrm{~min}, 4^{\circ} \mathrm{C}\right)$. Once supernatant was removed and discarded (leaving approx. $10 \mu \mathrm{L}$ ), $\mathrm{H}_{2} \mathrm{O}_{2}$ was added to the cellular pellet. Following incubation $\left(1 \mathrm{~h}, 4^{\circ} \mathrm{C}\right.$, dark) samples were spun (as before), supernatant removed and samples processed as detailed below.

Briefly, cells (100 $\mu \mathrm{l}$, section 2.4.1) were secured onto coverslips using a slide centrifuge (Cytospin 4, Thermo Fisher Scientific Inc., Waltham, MA, USA, 800 rpm) for $5 \mathrm{~min}$. Coverslips were placed in individual wells (6 well plate, sterile, Greiner Bio-One), chilled $\left(20 \mathrm{~min}, 4^{\circ} \mathrm{C}\right.$ ) to allow adhering and fixed with ice-cold Carnoys solution for $20 \mathrm{~min}$ at room temperature (75\% methanol, $25 \%$ glacial acetic acid, $1 \mathrm{~mL}$ per well). Subsequent to fixation, coverslips were rinsed with PBS (Dulbecco, Fisher) in triplicate.

Cells were permeabilised (10 min, 0.5\% Triton X-100 in PBS, room temp), blocked (1.5 h, normal goat serum, $60 \mu \mathrm{l}$ per coverslip, G9023, Sigma) and rinsed in triplicate with $0.1 \%$ Triton X-100/PBS. Cells were incubated overnight $\left(4^{\circ} \mathrm{C}\right)$ with the primary antibody $(60 \mu \mathrm{l}$ per slide, 1:10000 in 0.1\% Triton X-100/PBS, anti-GamaH2H [Y-H2AX], Merck Millipore, UK). Procedural blanks were run alongside samples, with no primary antibody. Following a rinse (in triplicate, $0.1 \%$ Triton $X-100 / P B S$ ) cells were incubated in the dark with a secondary antibody, at room temperature $(1 \mathrm{~h}, 60 \mu \mathrm{l}$ per slides, 1:1000 in $0.1 \%$ Triton $\mathrm{X}$ 100/PBS, Anti-IgG secondary antibody), and then rinsed as before.

Cells were counterstained with DAPI (1 $\mu \mathrm{g} 10 \mathrm{~mL}^{-1}$ PBS) for $10 \mathrm{~min}$ in the dark. Subsequent to rinsing (in duplicate, distilled water), coverslips were gently removed from well plates, tilted to remove excess liquid and mounted onto labelled slides. Slides were scored (50 cells per individual) by counting number of foci per cell using a fluorescence microscope (Nikon fluorescence microscope, 60x magnification). As described by Festarini et al [70], cell nuclei were located with an appropriate DAPI filter, and a FITC filter set for the FITC signal of the $\mathrm{Y}-\mathrm{H} 2 \mathrm{AX}$ primary antibody. All slides, including procedural blanks were coded and scored at random. 


\subsection{Statistical analysis}

All statistical analyses were carried out using the statistical software R (RStudio, R 3.4.3 GUI 1.70 El Capitan build (7463), https://www.r-project.org/). All data was checked for normality distribution (Shapiro-Wilk test) and homogeneity of variances (Levene's test), with visual examination of QQ-plots. The non-parametric Kruskal-Wallis test was used if assumptions were not met; comparison between treatment groups was determined using a Dunn's pairwise comparison with Bonferroni correction. Where assumptions were met, a one-way ANOVA was run with Tukey's post hoc tests. Comparison between treatment groups was determined using a Wilcoxon rank sum test with Holm-Bonferroni correction. Regression analysis, using a Pearson correlation coefficient was used to determine any correlations between variables. Level of significance for all tests was set at $p<0.05\left(^{*}\right)$ and data presented as mean \pm standard deviation, unless otherwise stated.

\section{Results}

No spawning of mussels occurred during the duration of the experiments and mortality remained low throughout, with one fatality in the highest $\mathrm{Cu}$ treatment (MG, $56 \mu \mathrm{g} \mathrm{L}^{-1}$, EXP1). Metal concentration and water quality measurements are displayed in table 1, results of the ICP-MS analysis confirmed that achieved values were in line with expected Cu concentrations across all treatments.

\subsection{Tissue specific $\mathrm{Cu}$ accumulation}

After a 10-day exposure a substantial accumulation of $\mathrm{Cu}$ in both bivalve species was observed. Fig. 2 highlights the variable nature of tissue specific uptake. Cu accumulation occurred in a concentration dependant manner in all tissues but the mantle of both species, MG 'other' soft tissue, and DP adductor muscle. Cu uptake varied between tissue, and between species. Concentrations ranged between 8.7 and $311.4 \mu \mathrm{g} \mathrm{g}^{-1}$, with the highest levels evident in gill and digestive gland, independent of species. In the highest treatment group $\left(56 \mu \mathrm{g} \mathrm{L}^{-1}\right)$, accumulation varied in the order of gill > digestive gland > other soft tissue > mantle > adductor muscle in MG, and digestive gland > gill > mantle > other soft tissue > adductor muscle in DP. In terms of whole soft tissue (sum of all tissue), DP had a greater degree of accumulation than $M G$ in all but the highest treatment group. In the 32 $\mu \mathrm{g} \mathrm{L}^{-1}$ treatment, the accumulation of $\mathrm{Cu}$ in $\mathrm{DP}\left(458 \mu \mathrm{g} \mathrm{g}^{-1}\right)$ was 1.2 times higher than in MG (382 $\left.\mathrm{Mg} \mathrm{g}^{-1}\right)$, and approx. 2 times higher in control treatments. 


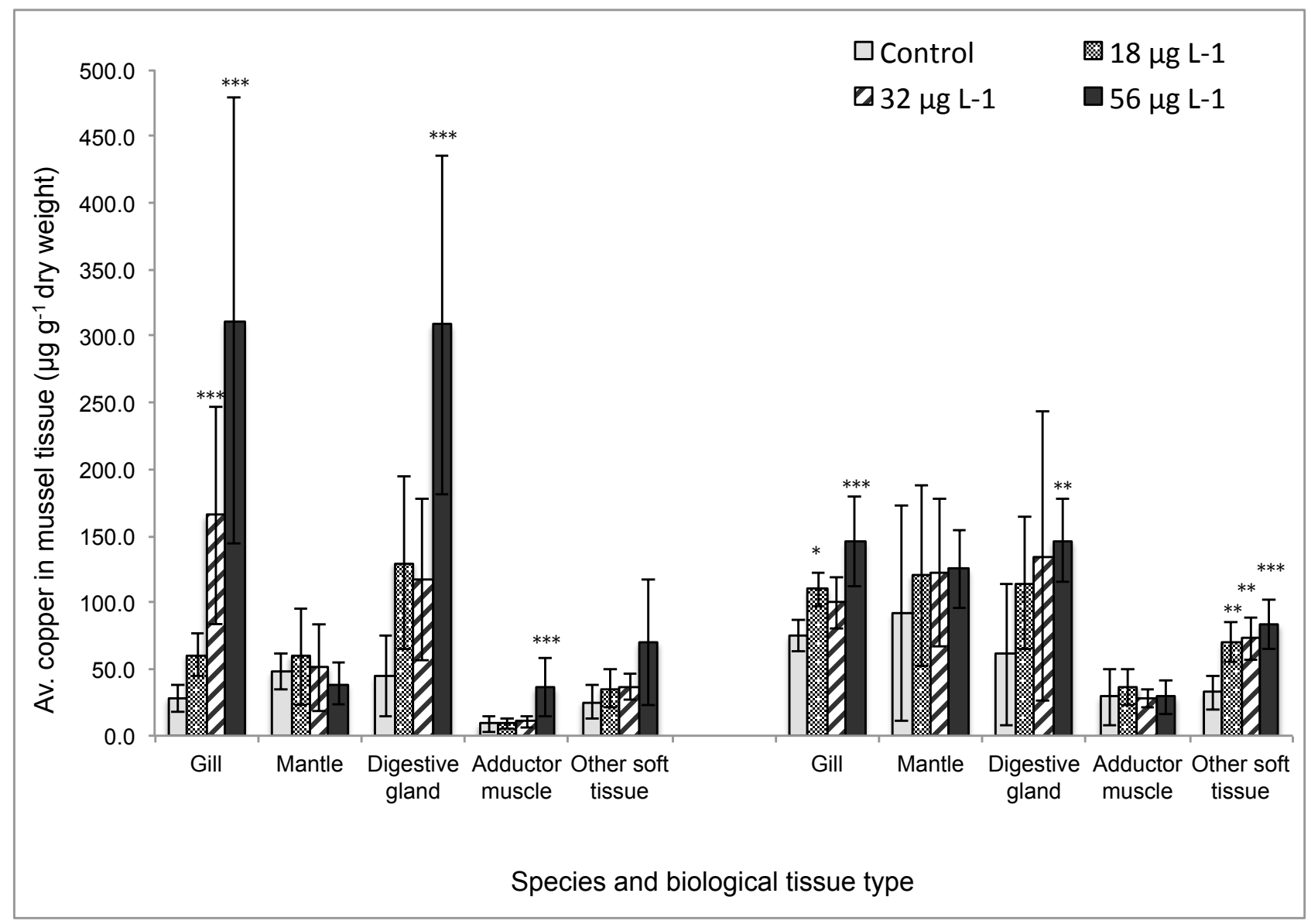

Figure 2. Tissue specific accumulation of copper in M. galloprovincialis (left) and D. polymorpha (right), microgram per gram of mussel tissue (dry weight) in control and exposed treatment groups. Asterisks $\left({ }^{*},{ }^{* *}\right.$ or $\left.{ }^{* * *}\right)$ are indicative of significant differences $(p<0.05,0.01,0.001)$ from the corresponding control. SD is standard deviation of mean data. $n=9$.

Biological response clearly correlated with the level of $\mathrm{Cu}$ accumulation in gill tissue, where the highest genotoxic response was found in mussels exposed to the two highest Cu concentrations (Fig. 3). 

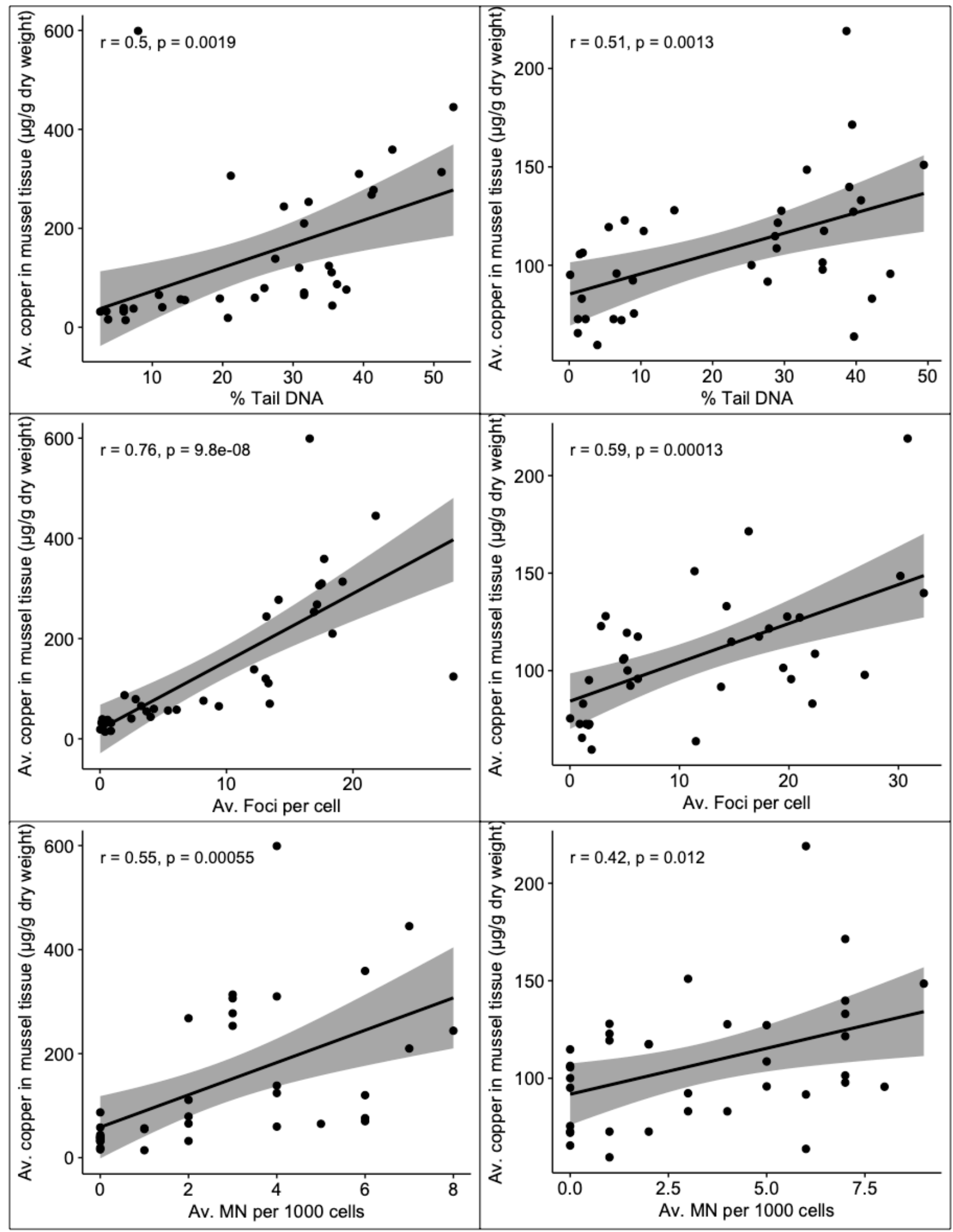

Figure 3. Pearson's correlation analyses of $\mathrm{Cu}$ accumulation in gill tissue. Top to bottom: DNA damage (\% tail DNA), induction of $\mathrm{y}-\mathrm{H} 2 \mathrm{AX}$ foci and micronuclei (MN) formation in $M$. galloprovincialis (left) and $D$. polymorpha (right). $n=9$. 


\subsection{Genotoxic effects and repair capacity in mussel gill cells}

\subsubsection{In-vitro validation of comet and $\mathrm{y}-\mathrm{H} 2 \mathrm{AX}$ assays}

Fig. 4 provides the representative photographs of the DNA damage (as determined by the comet assay) and induction of $\mathrm{y}-\mathrm{H} 2 \mathrm{AX}$ foci in gill cells of DP following in vitro validation studies using hydrogen peroxide $\left(\mathrm{H}_{2} \mathrm{O}_{2}\right)$. Fig. 5 shows the mean (+ S.D) number of $\gamma$ $\mathrm{H} 2 \mathrm{AX}$ foci, and \% Tail DNA in MG and DP gill cells following exposure to varying concentrations of $\mathrm{H}_{2} \mathrm{O}_{2}$. In both species, $\mathrm{H}_{2} \mathrm{O}_{2}$ produced a concentration-dependent increase for increased \% Tail DNA ( $p=0.01$ and $p=0.001)$ and for the number of foci per cell ( $p=0.01$ and $p=0.04)$ compared to controls for both the species (Figure 5A and B).

$<$ Insert Figure 4 and 5>
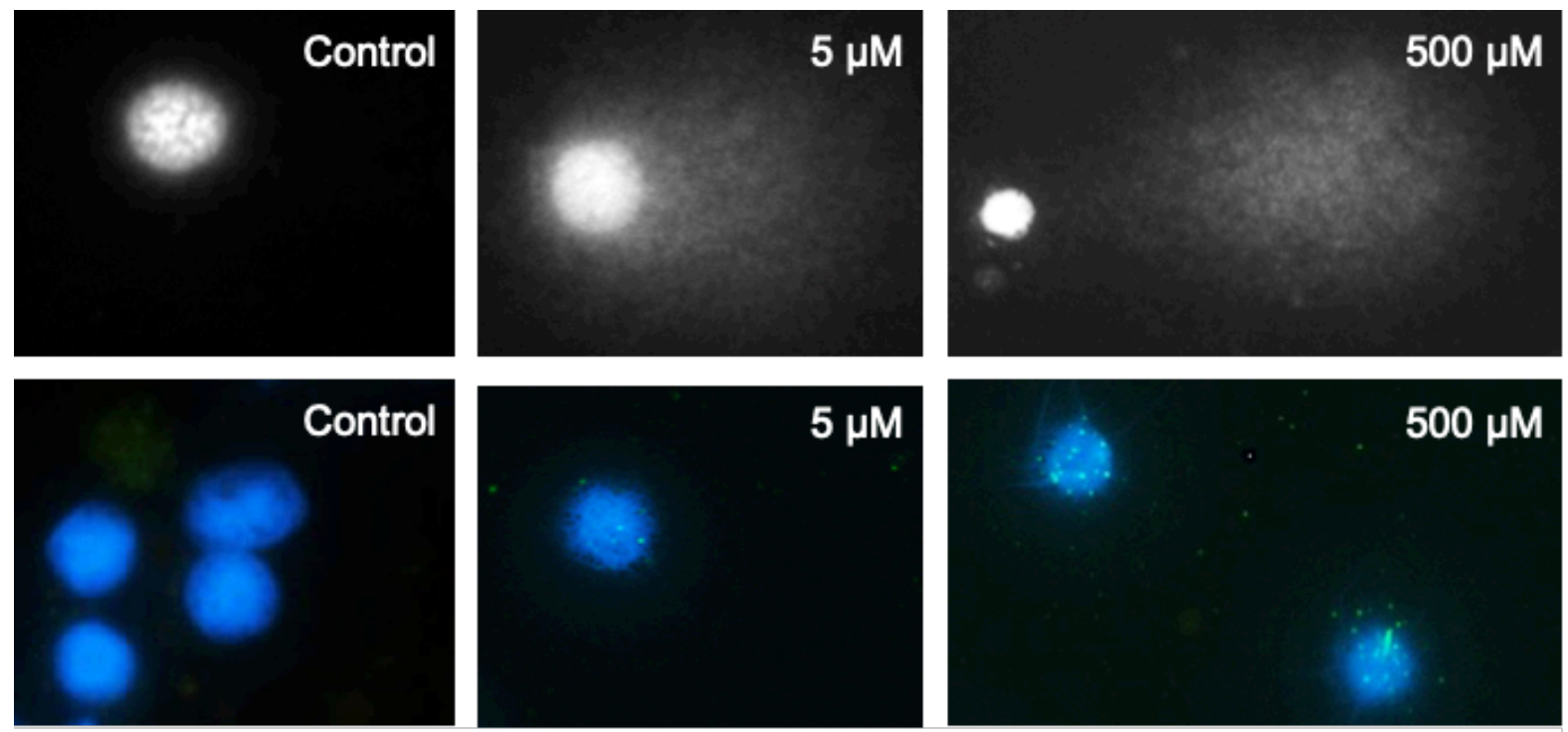

Figure 4. Photomicrographs showing DNA damage, as measured by $\%$ Tail DNA (top) and induction of $\mathrm{y}-\mathrm{H} 2 \mathrm{AX}$-foci (bottom) in gills cells of $D$. polymorpha following a $1 \mathrm{~h}$ exposure to varying $\mathrm{H}_{2} \mathrm{O}_{2}$ concentrations. 


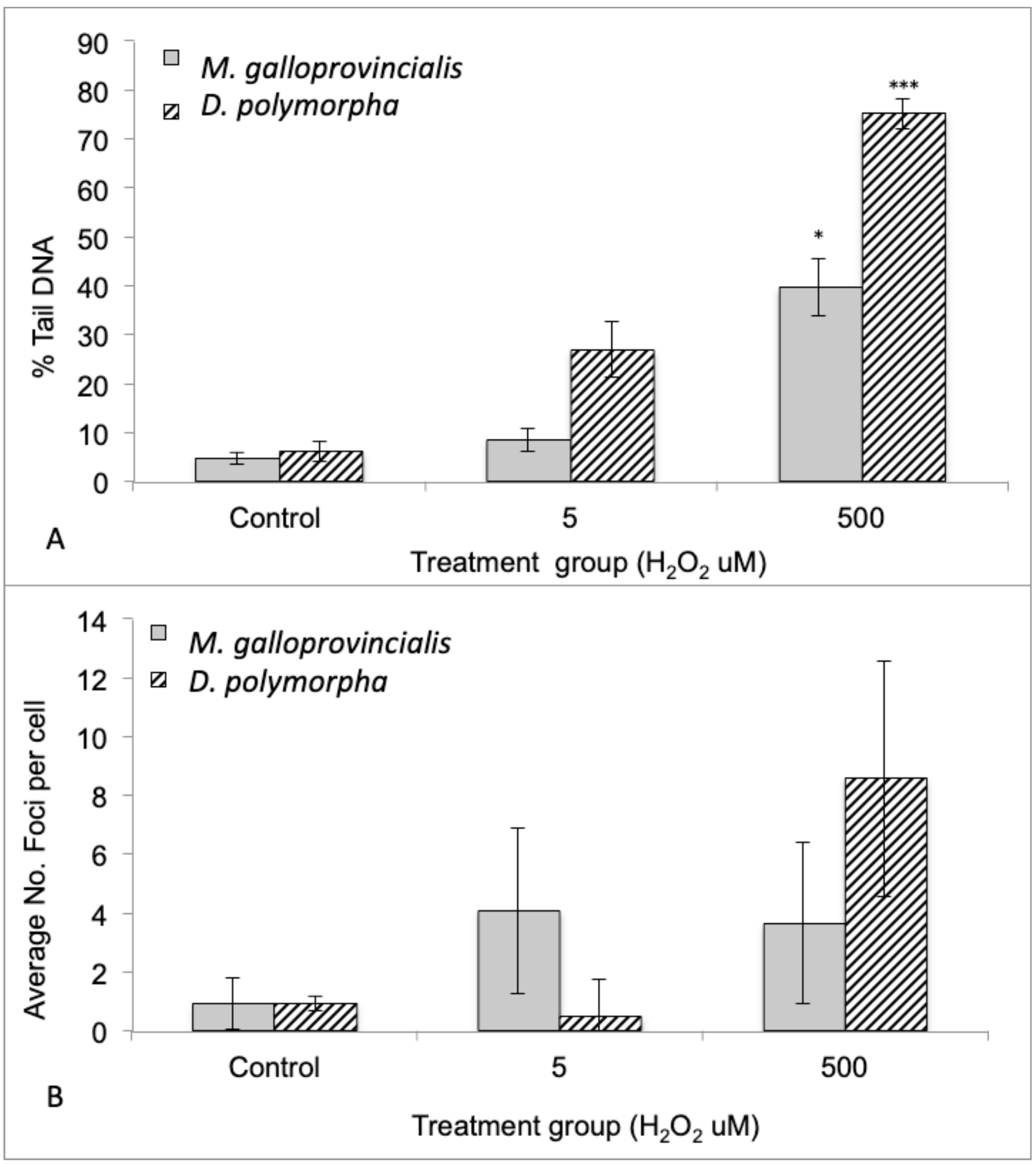

Figure 5. Graphs to show (A) DNA damage (Tail \% DNA) and (B) average number of $\gamma-\mathrm{H} 2 \mathrm{AX}$ foci in $M$. galloprovincialis and $D$. polymorpha gill cells following exposure to varying concentrations of hydrogen peroxide. SD is standard deviation of mean data. Asterisks $\left({ }^{*},{ }^{* *}\right.$ or $\left.{ }^{* \star *}\right)$ are indicative of significant differences $(p<0.05,0.01,0.001)$ from the corresponding control. $n=4$. 


\subsubsection{Genotoxic response following in vivo exposures to $\mathrm{Cu}$}

Fig. 6A, B and $\mathrm{C}$ show the mean (+ S.D) \% tail DNA damage, micronuclei per 1000 cells and $\mathrm{Y}-\mathrm{H} 2 \mathrm{AX}$ foci induction respectively in the gill cells of the two species following exposure to varying $\mathrm{Cu}$ concentrations for 10 days. Both the species showed genotoxic effects following $\mathrm{Cu}$ exposure compared to controls. Independent of species a concentration dependant increase was evident across all genotoxic biomarkers in response to $\mathrm{Cu}(p<0.001)$. 


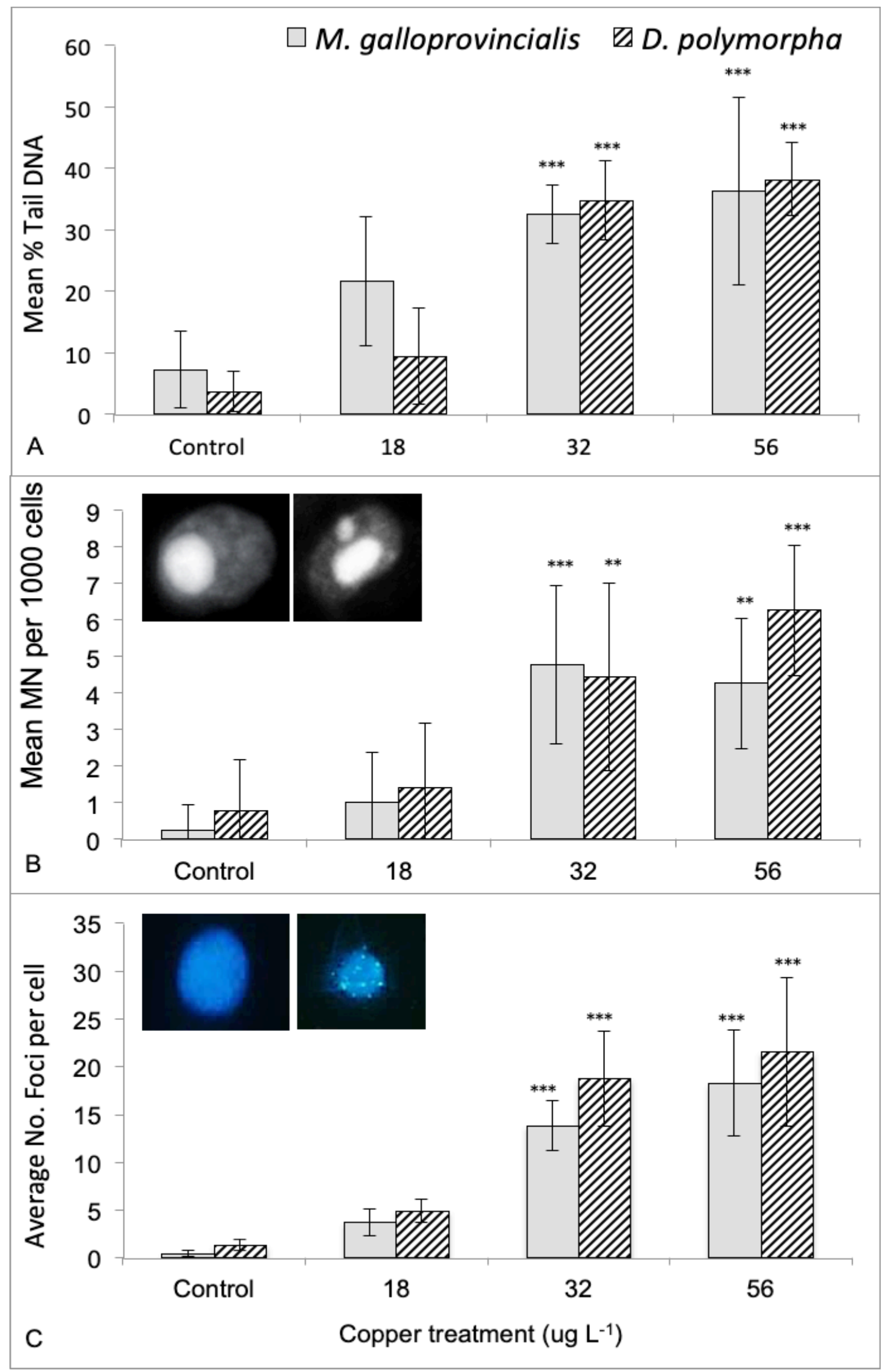

Figure 6. Genotoxic responses in $M$. galloprovincialis and $D$. polymorpha gill cells following a 10 day exposure to copper $(\mathrm{Cu})$. (A) DNA damage (\% tail DNA), (B) Induction of micronuclei (MN) and (C) induction of $\gamma-\mathrm{H} 2 \mathrm{AX}$ foci Asterisks $\left({ }^{*},{ }^{* *}\right.$ or $\left.{ }^{* * *}\right)$ are indicative of significant differences $(p<0.05$, $0.01,0.001)$ from the corresponding control. SD is standard deviation of mean data. Images show (left) control cell and (right) damaged cell. $n=9$. 
Although a genotoxic response was evident in the lowest $\mathrm{Cu}$ treatment for all biomarkers studied, a significant response was evident only for 32 and $56 \mu \mathrm{g} \mathrm{L}^{-1}$ treatments compared to the controls. Interestingly, there was no significant difference in response between the 32 and $56 \mu \mathrm{g} \mathrm{L}^{-1}$ treatments in either species. In the highest concentration (i.e. $56 \mu \mathrm{g} \mathrm{L}^{-1}$ $\mathrm{Cu}$ ) the average level of induced $\mathrm{Y}-\mathrm{H} 2 \mathrm{AX}$ foci per cell was $18 \pm 6$ and $22 \pm 8$ foci per cell in MG and DP, compared with $0.4 \pm 0.3$ and $1 \pm 0.6$ foci per cell for control treatments. For both species, the observed response for $\mathrm{y}-\mathrm{H} 2 \mathrm{AX}$ showed a strong correlation with DNA damage $(p<0.001)$ and MN formation $(p<0.001$, Fig. 7$)$. The $\%$ tail DNA in the highest treatment averaged around $37 \%$ (both species), as expected a low degree of damage was evident in control treatments. DNA damage in individuals exposed to the highest $\mathrm{Cu}$ concentrations was 5 and 9.5 times higher in MG and DP, in comparison to the control. In terms of species comparison, despite disparity in $\mathrm{Cu}$ accumulation among the tissues, there was little variation in genotoxic response in the cells. The only significant variation occurred between $\mathrm{y}-\mathrm{H} 2 \mathrm{AX}$ foci induction in control cells $(p<0.05)$. 


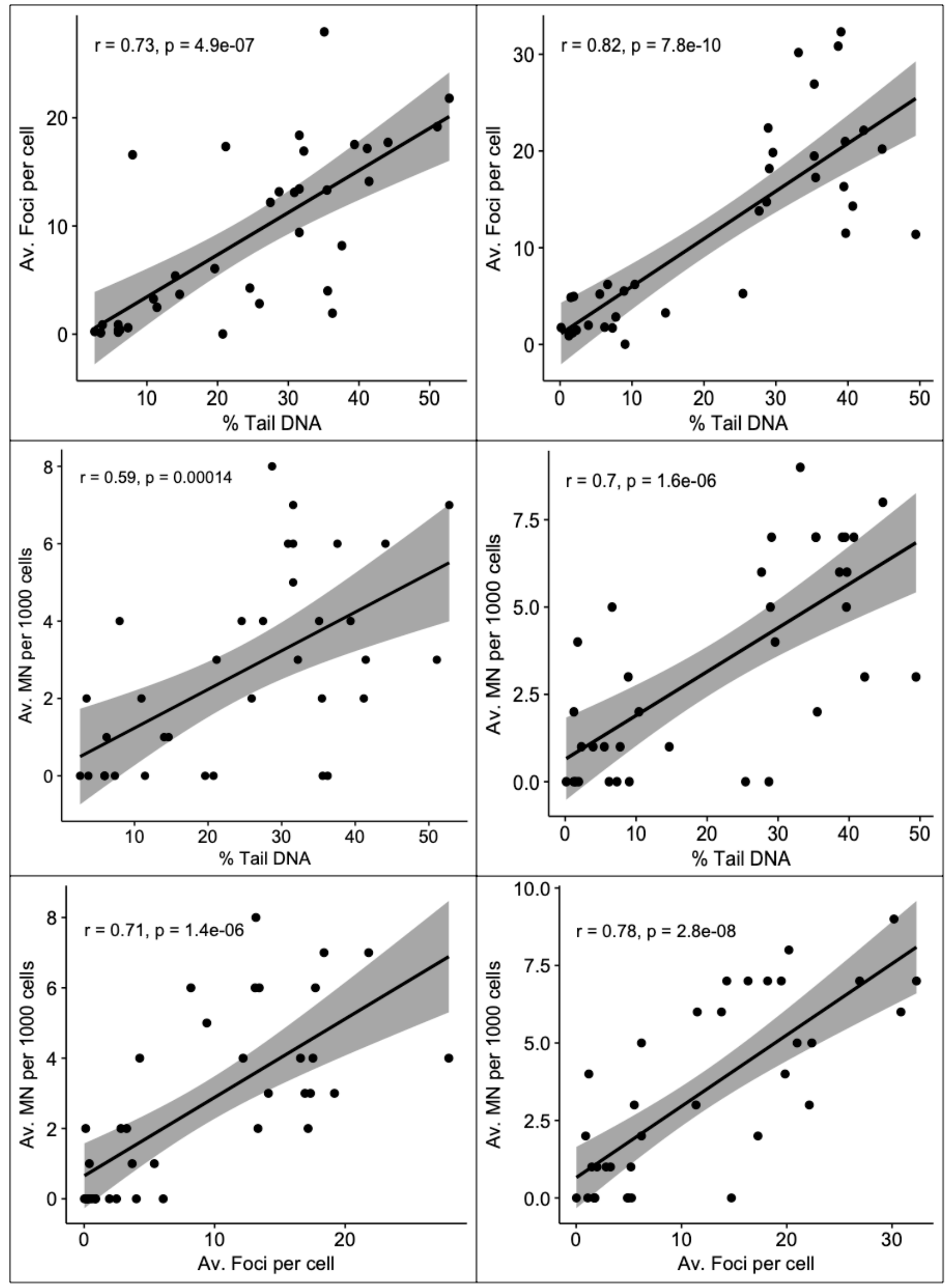

Figure 7. Pearson's correlation analyses. Top to bottom: \% tail DNA and induction of $\mathrm{Y}-\mathrm{H} 2 \mathrm{AX}$ foci; \% tail DNA and induction of $\mathrm{MN}$ and induction of $\mathrm{MN}$ and $\mathrm{y}-\mathrm{H} 2 \mathrm{AX}$ foci in $M$. galloprovincialis (left) and D. polymorpha (right). $n=9$. 


\section{Discussions}

\subsection{Tissue-specific $\mathrm{Cu}$ accumulation}

It is well accepted that following uptake, waterborne contaminants are not uniformly distributed among the tissues due to their inherent metabolic capabilities [4,17, 37, 71-74]. The presence of metals in the sediments has also been correlated with their accumulation in soft tissues of bivalves under field conditions [4]. As expected, in our study $\mathrm{Cu}$ concentrations varied among the tissues [75-78]. The highest $\mathrm{Cu}$ concentrations were found in the gill and digestive gland, particularly in the MG $56 \mu \mathrm{g} \mathrm{L}^{-1}$ treatment. In this treatment, $40 \%$ (MG) and 28\% (DP) of accumulated Cu was located in the digestive gland, this is in contrast to previous report where $\mathrm{Cu}$ in DP had been shown to predominately accumulate in the foot (included in other soft tissue in this study), followed by gill and digestive organs [79]. Mussel digestive systems are well known to harbour contaminants via dietary uptake pathways [22,74, 80-81]. Apart from inherent metabolic differences, uptake and bioaccumulation is dependent on many factors including bioavailability, uptake mechanism and biological factors (e.g. weight, gender, reproductive stage, feeding habits etc.). These factors may help explain disparity between the studies [2].

In line with findings from Sanders et al. [82], Zorita et al. [83] and Al-Subiai et al. [17], a high degree of $\mathrm{Cu}$ bioaccumulation was evident in gill tissue of both species. Bivalve gills, due to proximity to surrounding media and therefore the primary sites of uptake of dissolved $\mathrm{Cu}$, are often regarded as a key tissue of interest in ecotoxicological studies. In contrast to Al-Subiai et al. [17], who found reduced $\mathrm{Cu}$ accumulation in $56 \mathrm{mg} \mathrm{L}^{-1}$ compared to $32 \mathrm{mg} \mathrm{L}^{-1}$ treatment across all tissue (adductor muscle, digestive gland, gills), in our study accumulation increased in a concentration dependant manner in accordance to external $\mathrm{Cu}$ concentration (all but the MG mantle and DP adductor muscle tissue, Fig. 2). These differences may result from varying experimental procedures, including shorter exposure length or varying feeding regimes (i.e. individuals fed/not fed). Cu bioaccumulation and subsequent biological response in Mytilus sp. has been investigated by Brooks et al. [32], who found an increased rate of bioaccumulation in $M$. trossulus compared to $M$. edulis/galloprovincialis ( $4 \mathrm{~d}, 500 \mathrm{\mu g} \mathrm{L}^{-1}$ ), and a higher prevalence of $\mathrm{MN}$ in $M$. edulis compared to $M$. trossulus. The mussels included in this study were collected from three different geographical locations (i.e. Norway and the Basque country, Spain). Hybridization and introgression of geographically dispersed species could play an important role in the bioaccumulative potential of contaminants, and may explain the differences found between biological studies [17,32, 84]. A more complete introgression 
analysis that is not assessed by the Glú-5 gene (nuclear DNA marker used to characterise Mytilus sp.) may help to identify species differences that affect contaminant uptake [85-86].

Whole soft tissue $\mathrm{Cu}$ concentrations were reflective of exposure with accumulation occurring in a concentration dependant manner. Interestingly, in all but the highest treatment DP showed a greater degree of $\mathrm{Cu}$ accumulation in whole soft tissue, uptake in DP also appeared to be more evenly distributed across specific tissues. It is important to note that differential $\mathrm{Cu}$ speciation in water bodies may affect its bioavailability and subsequent toxicity to aquatic biota. The physical and chemical form of $\mathrm{Cu}$, with focus on the toxic ionic form $\left(\mathrm{Cu}^{2+}\right)$ varies between salt and freshwater environments, becoming more abundant at lower salinities [87]. The influence of water parameters (i.e. $\mathrm{pH}$, salinity, dissolved organic carbon [DOC], alkalinity) in affecting $\mathrm{Cu}$ bioavailability and toxicity may explain disparities present within our data, along with differential physiology [88-90]. As certain parameters (e.g. DOC) were not determined during this experiment, we are unable to determine if the species disparity resulted from varying water chemistry, especially DOC or differential species sensitivity. In both species independently, however, correlation between accumulations of $\mathrm{Cu}$ in soft tissues with increasing genotoxicity in gill cells were evident.

\section{2 $\mathrm{Cu}$ induced genotoxicity in gill cells}

The capacity of $\mathrm{Cu}$ to induce chromosomal damage in a range of cell types has previously been reported in MG [32, 91], and in DP in response to a range of contaminants [92-94]. As mentioned earlier, $\mathrm{Cu}$ accumulation in mussel tissue is significantly correlated with the adverse genotoxicological effects noted in both the species (Fig. 3). Cu toxicity in marine bivalves has been demonstrated extensively in scientific literature [6,17, 24, 95], along with freshwater species [96-98]. In line with previous studies, significant effects (i.e. DNA strand breaks and $\mathrm{MN}$ induction) were evident in both marine and freshwater mussels exposed to the highest $\mathrm{Cu}$ concentrations (32 and $56 \mu \mathrm{g} \mathrm{L}^{-1}$ ), with a 4-9 fold increase in DNA damage relative to controls. The genotoxicity of $\mathrm{Cu}$ in mussel gill cells may be related to the overproduction of ROS, leading to oxidative damage in the form of single and double strand DNA breaks (SSBs and DSBs), base modifications or oxidation of bases [8]. Furthermore, $\mathrm{Cu}^{2+}$ is known to bind to DNA, forming adducts [99].

While MG individuals showed greater $\mathrm{Cu}$ concentrations in gill tissue there was a high degree of comparability between species response, suggesting that $\mathrm{Cu}$ toxicity is not necessarily related to accumulation. In terms of the comet assay results, both species 
showed around 34-38\% damage (\% Tail DNA) in two highest $\mathrm{Cu}$ concentrations. Background levels of DNA damage in the controls were around $7 \pm 6$ (MG) and $4 \pm 3 \%$ (DP, \% Tail DNA), relatable to previous findings $[3,5,71,100]$, this suggests general good health of the unexposed (control) individuals. Interestingly, Cu genotoxicity was not significantly evident at the lowest concentrations $\left(18 \mu \mathrm{g} \mathrm{L}^{-1}\right)$, in either species. This is contrast to Anjos et al. [101] who found significantly increased DNA damage in sea anemone (B. cangicum) pedal disk cells exposed to much lower $\mathrm{Cu}$ concentrations $\left(7.8 \mu \mathrm{g} \mathrm{L}^{-1}, 24 \mathrm{~h}\right)$. Our data was also in contrast to that of Al-Subiai et al. [17], who noted significantly increased DNA damage in Mytilus edulis at $18 \mu \mathrm{g} \mathrm{L}^{-1}$, following a 5 day $\mathrm{Cu}$ exposure. As mentioned above, several biological and physico-chemical factors could account for these differences [2].

As previously mentioned, direct species comparison is limited due to differing water chemistry, potentially altering bioavailability. In addition, tissue $\mathrm{Cu}$ concentration is not necessarily a reliable indicator of toxicity. It is only a proportion of metal that interacts with sensitive target molecules (i.e. DNA) that induces a toxic effect. Despite this, it is clear that even at low tissue concentrations a genotoxic response is present in both species. Larsson et al. [84] found a lack of difference in response to environmental stressors between marine mussels collected from reference and contaminated sites (i.e. sewage treatment plants, harbours) around the Baltic Sea region. The authors suggest that the presence of strong introgression between the two Mytilus taxa, along with adaptation to the specific environmental conditions could have accounted for this lack of differential sensitivity [84]. In our study, the similarity in DNA damaging effects suggests a similar mechanism of action in response to pollutants in the two species.

This study highlights the potential of zebra mussels (DP) as a freshwater equivalent to Mytilus species. Due to their ubiquitous, invasive nature they are regarded as a fairly tolerant, insensitive species [96]. As with Mytilus spp., a range of cell types from gill to haemocytes can be successfully utilised in biological assays. As expected, in this study damage to DNA and MN formation was significantly correlated, in both species. Previous studies from our laboratory have reported significant correlations between induction of MN and DNA strand breaks in mussels and sea stars following exposures to environmentally relevant metals and pharmaceuticals [3,5]. In the present study, it was interesting to note very good correlations between induction of $\mathrm{Y}-\mathrm{H} 2 \mathrm{AX}$ foci with DNA strand breaks and micronuclei (Fig. 7). Such a relationship is increasingly recognized in mammalian in vitro studies [102]. To our knowledge, such correlations between different genotoxicity parameters, especially in aquatic organisms have not been reported previously. The 
combined use of these biomarkers allows for holistic determination of the genotoxic damage induced by environmental agents which could be applied to other natural species.

One interesting aspect observed in this study is while no significant difference in terms of DNA damage is evident between the highest concentrations $\left(32,56 \mu \mathrm{g} \mathrm{L}^{-1}\right.$, both species), there is a slight increase in $\mathrm{Y}-\mathrm{H} 2 \mathrm{AX}$ foci in the $56 \mathrm{\mu g} \mathrm{L}^{-1}$ treatment. This could be a result of increased DSBs in the highest treatment, as opposed to less detrimental DNA lesions (i.e. single strand breaks) at lower $\mathrm{Cu}$ concentrations. $\mathrm{Y}-\mathrm{H} 2 \mathrm{AX}$ foci were present in the lowest $\mathrm{Cu}$ concentrations $\left(18 \mu \mathrm{g} \mathrm{L}^{-1}\right)$, where the genotoxicity of $\mathrm{Cu}$ was not significantly apparent. Our data suggests that while DNA damage was not evident using the comet or MN assays, possibly due to lack of sensitivity, $\mathrm{Y}-\mathrm{H} 2 \mathrm{AX}$ is being recruited to damaged sites, in turn recruiting other DNA repair machinery even at low Cu concentrations.

In terms of relative sensitivity of the comet and induction of $\mathrm{y}-\mathrm{H} 2 \mathrm{AX}$ assays, one major drawback of the comet assay is its inability to discriminate between DNA lesions, such as single and double SBs, alkali labile sites and DNA interstrand crosslinks [63,103-106]. DSBs are considered to be most detrimental form of damage, they may be repaired or result in apoptosis and/or mutation. Induction of $\mathrm{y}-\mathrm{H} 2 \mathrm{AX}$ is increasingly used as a biomarker in combination with classical and molecular techniques in mammalian systems $[48,68,102]$. Whilst these techniques are considered to be simple and rapid (fast analysis time) in comparison to many other established methodologies [106], their relative sensitivity and effectiveness have not been compared sufficiently in ecotoxicological studies. In this study, we compared the classical and novel techniques, examining their sensitivity as well as cost/time effectiveness. Although the biological damage measured by Comet and induction of $\mathrm{Y}-\mathrm{H} 2 \mathrm{AX}$ assays are mechanistically different (one reflecting SSBs/DSBs, alkali labile site and another only DSBs), the alkaline comet assay appears to be more suitable for larger sample sizes that have high levels of DNA damage. On the other hand induction of $\mathrm{Y}-\mathrm{H} 2 \mathrm{AX}$ foci, due to its high sensitivity could be considered more suitable for studies which aim to determine DNA damage at lower levels of exposure, to those genotoxicants capable of effectively inducing DSBs. This is particularly so as at higher levels of damage, induced foci can overlap making the scoring difficult and timeconsuming. Overall, induction of $\mathrm{y}-\mathrm{H} 2 \mathrm{AX}$ foci has proved useful as a highly sensitive technique for detecting low-levels of DNA damage, its usefulness in ecotoxicological research, when combined with more classical techniques is clear. 
$\mathrm{Cu}$, as a model toxic metal is known to induce various types of damage to DNA and chromatin with potential pathophysiological consequences [8,10]. As mentioned earlier, one of the important mechanisms of induction of damage by $\mathrm{Cu}$ is via generation of reactive oxygen species (ROS or free radicals) inducing oxidative stress to biomolecules including DNA $[8,10]$. Modified comet assays using bacterial enzymes (e.g. FPG, Endo III) have been used by different workers to determine DNA oxidation in fish and mussels $[5,107]$. It would have been useful to determine DNA oxidation using the modified comet assay in this study as well, to determine relative contribution of DNA oxidation. This was however not feasible due to logistical problems. In addition, $\mathrm{Cu}$ in common with other toxic metals (e.g. As, Co, $\mathrm{Cd}, \mathrm{Ni}$ ) could also interfere with DNA repair processes and cell cycle control [11]. In common with mammalian studies, elucidation of these fundamental processes in aquatic organisms following exposures to environmental contaminants also warrants attention. Interpreting these highly conserved processes would help to further strengthen human and environmental links.

\section{Conclusions}

Our study has been the first to compare tissue specific accumulation and genotoxic effects following exposure to $\mathrm{Cu}$ in marine and freshwater bivalve gill cells. The zebra mussel, DP, is increasingly being utilised as a freshwater counterpart of Mytilus spp. in biomonitoring and ecotoxicological research. Our data highlights a clear relationship between external (water) and internal $\mathrm{Cu}$ concentrations. The capacity to concentrate contaminants within tissue makes MG and DP suitable bioindicator species to assess environmental health. $\mathrm{Cu}$ induced comparable chromosomal and DNA damage in both mussel species, despite variable bioaccumulation of $\mathrm{Cu}$ into gill tissue. Furthermore, induction of $\mathrm{Y}-\mathrm{H} 2 \mathrm{AX}$ foci formation was successfully applied as a useful biomarker of contaminant induced genotoxicity. The usefulness of this assay, particularly when applied alongside more classical, established techniques such as MN and comet assays is evident.

The relative sensitivity of species could vary depending upon the mechanisms or mode of actions of genotoxicants. For use in biomonitoring, it is important to validate the $\mathrm{Y}-\mathrm{H} 2 \mathrm{AX}$ and other assays further in a wider range of aquatic biota, to well established genotoxic pollutants with different mechanisms or mode of action, before their applications in the field conditions. While we cannot definitively associate the relative comparability in genotoxic response to differential species sensitivity following exposure to a novel metallic toxicants, our results suggest that even low, environmentally realistic $\mathrm{Cu}$ concentrations have the 
potential to cause stress to some bivalve molluscs. For adequate protection of coastal and inland water bodies, future research would benefit from using a multi-species, multibiomarker approach when investigating adverse effects at varying levels of biological organisation to gain a true understanding of the real environmental threat of the contamination to aquatic biota.

\section{Conflict of interest:}

Authors declare no conflict of interest.

\section{Acknowledgments}

We thank Dr Andrew Fisher for his technical advice during ICP-MS analysis, Dr Lorna Dallas for help and guidance during the running of experiments and subsequent data organisation and Dr Deepu Oommen for optimisation of $\mathrm{y}-\mathrm{H} 2 \mathrm{AX}$ technique. This work has been funded by the Natural Environment Research Council (NERC), the Environment Agency (EA) and Radioactive Waste Management Limited (RWM) under the Radioactivity and the Environment (RATE) programme, UK (Grant no.: NE/L000393/1). 


\section{References}

1. Jha AN (2004) Genotoxicological studies in aquatic organisms: an overview. (invited review article). Mutation Research (Fundamental and Molecular Mechanisms of Mutagenesis): 552, 1-17.

2. Jha AN (2008) Ecotoxicological applications and significance of the comet assay. Mutagenesis 23: 207-221. doi 10.1093/mutage/gen014

3. Canty MN, Hutchinson TH, Brown RJ, Jones MB, Jha AN (2009) Linking genotoxic responses with cytotoxic and behavioural or physiological consequences: differential sensitivity of marine molluscs (Mytilus edulis) and echinoderms (Asterias rubens). Aquatic Toxicology 94, 68-76.

4. Dallas LJ, Cheung VV, Fisher AS, Jha AN (2013a) Relative Sensitivity of Two Marine Bivalves for Detection of Genotoxic and Cytotoxic Effects: A Field Assessment in the Tamar Estuary, South West England. Environmental Monitoring \& Assessment 85, 33973412.

5. Dallas LJ, Bean TP, Turner A, Lyons BP, Jha AN (2013b) Oxidative DNA damage may not mediate $\mathrm{Ni}$-induced genotoxicity in marine mussels: Assessment of genotoxic biomarkers and transcriptional responses of key stress genes. Mutation Research/Genetic Toxicology and Environmental Mutagenesis 754: 22-31. doi http://dx.doi.org/10.1016/j.mrgentox.2013.03.009

6. Bolognesi C, Landini E, Roggieri P, Fabbri R, Viarengo A (1999) Genotoxicity biomarkers in the assessment of heavy metal effects in mussels: experimental studies. Environmental and Molecular Mutagenesis 33: 287-292.

7. Stohs SJ, Bagchi D (1995) Oxidative mechanisms in the toxicity of metal ions. Free radical biology \& medicine 18: 321-336

8. Lloyd DR, Phillips DH (1999) Oxidative DNA damage mediated by copper(II), iron(II) and nickel(II) Fenton reactions: evidence for site-specific mechanisms in the formation of double-strand breaks, 8-hydroxydeoxyguanosine and putative intrastrand cross-links. Mutation Research/Fundamental and Molecular Mechanisms of Mutagenesis 424: 23-36. doi https://doi.org/10.1016/S0027-5107(99)00005-6

9. Azqueta A, Lorenzo Y Fau, Collins AR (2009) In vitro comet assay for DNA repair: a warning concerning application to cultured cells Mutagenesis. Jul 24(4):379-81. doi: 10.1093/mutage/gep009.

10. Linder MC (2012) The relationship of copper to DNA damage and damage prevention in humans. Mutation Research 733, 83-91.

11. Hartwig A (2013) Metal interaction with redox regulation: an integrating concept in metal carcinogenesis. Free Radical Biology and Medicine 55, 63-72.

12. Xu M, Jiang L, Shen K-N, Wu C, He G, Hsiao C-D (2016) Transcriptome response to copper heavy metal stress in hard-shelled mussel (Mytilus coruscus). Genomics Data 7: 152-154. doi https://doi.org/10.1016/j.gdata.2015.12.010

13. Cid A, Herrero C, Torres E, Abalde J (1995) Copper toxicity on the marine microalga Phaeodactylum tricornutum: effects on photosynthesis and related parameters. Aquatic Toxicology 31: 165-174. doi http://dx.doi.org/10.1016/0166-445X(94)00071-W

14. Gaetke LM, Chow CK (2003) Copper toxicity, oxidative stress, and antioxidant nutrients. Toxicology 189: 147-163

15. Bopp SK, Abicht HK, Knauer K (2008) Copper-induced oxidative stress in rainbow trout gill cells. Aquatic Toxicology 86: 197-204. doi http://dx.doi.org/10.1016/j.aquatox.2007.10.014

16. Kim BE, Nevitt T, Thiele DJ (2008) Mechanisms for copper acquisition, distribution and regulation. Nature chemical biology 4: 176-185. doi 10.1038/nchembio.72

17. Al-Subiai SN, Moody AJ, Mustafa SA, Jha AN (2011) A multiple biomarker approach to investigate the effects of copper on the marine bivalve mollusc, Mytilus edulis.

Ecotoxicology and environmental safety 74: 1913-1920. doi http://dx.doi.org/10.1016/j.ecoenv.2011.07.012

18. Eisler R (1997) Copper hazards to fish, wildlife, and invertebrates: A synoptic review. Biological Science Report: 98

19. Donnachie RL, Johnson AC, Sumpter JP (2016) A rational approach to selecting and ranking some pharmaceuticals of concern for the aquatic environment and their relative 
importance compared with other chemicals. Environmental Toxicology and Chemistry 35: 1021-1027. doi doi:10.1002/etc. 3165

20. Bryan GW, Gibbs PE (1983) Heavy Metals in the Fal Estuary, Cornwall: A Study of Longterm Contamination by Mining Waste and Its Effects on Estuarine Organisms. Marine Biological Association of the United Kingdom.

21. DEFRA (2014) Water Framework Directive implementation in England and Wales: new and updated standards to protect the water environment. In: Environment FaRA (ed)

22. Viarengo A, Zanicchi G, Moore MN, Orunesu M (1981) Accumulation and detoxication of copper by the mussel Mytilus galloprovincialis Lam: A study of the subcellular distribution in the digestive gland cells. Aquatic Toxicology 1: 147-157. doi https://doi.org/10.1016/0166445X(81)90011-4

23. Geret F, Serafim A, Barreira L, João Bebianno M (2002) Response of antioxidant systems to copper in the gills of the clam Ruditapes decussatus. Marine Environmental Research 54: 413-417. doi http://dx.doi.org/10.1016/S0141-1136(02)00164-2

24. Brown RJ, Galloway TS, Lowe D, Browne MA, Dissanayake A, Jones MB, Depledge MH (2004) Differential sensitivity of three marine invertebrates to copper assessed using multiple biomarkers. Aquatic Toxicology 66: 267-278. doi http://dx.doi.org/10.1016/j.aquatox.2003.10.001

25. Villela IV, de Oliveira IM, da Silva J, Henriques JAP (2006) DNA damage and repair in haemolymph cells of golden mussel (Limnoperna fortunei) exposed to environmental contaminants. Mutation Research/Genetic Toxicology and Environmental Mutagenesis 605: 78-86. doi https://doi.org/10.1016/j.mrgentox.2006.02.006

26. Bolognesi C, Hayashi M (2011) Micronucleus assay in aquatic animals. Mutagenesis 26, 205-213.

27. Trevisan R, Ferraz Mello D, Fisher AS, Schuwerack P-M, Dafre AL, Moody AJ (2011) Selenium in water enhances antioxidant defenses and protects against copper-induced DNA damage in the blue mussel Mytilus edulis. Aquatic Toxicology 101: 64-71. doi http://dx.doi.org/10.1016/j.aquatox.2010.09.003

28. Bolognesi C, Fenech M (2012) Mussel micronucleus cytome assay. Nat Protocols 7: 11251137.

29. Mai H, Cachot J, Brune J, Geffard O, Belles A, Budzinski H, Morin B (2012) Embryotoxic and genotoxic effects of heavy metals and pesticides on early life stages of Pacific oyster (Crassostrea gigas). Marine pollution bulletin 64: 2663-2670. doi http://dx.doi.org/10.1016/j.marpolbul.2012.10.009

30. Vosloo D, Sara J, Vosloo A (2012) Acute responses of brown mussel (Perna perna) exposed to sub-lethal copper levels: integration of physiological and cellular responses. Aquat Toxicol 106-107: 1-8. doi 10.1016/j.aquatox.2011.10.001

31. Maria VL, Gomes T, Barreira L, Bebianno MJ (2013) Impact of benzo(a)pyrene, Cu and their mixture on the proteomic response of Mytilus galloprovincialis. Aquat Toxicol 144-145: 284-295. doi 10.1016/j.aquatox.2013.10.009

32. Brooks SJ, Farmen E, Heier LS, Blanco-Rayón E, Izagirre U (2015) Differences in copper bioaccumulation and biological responses in three Mytilus species. Aquatic Toxicology 160: 1-12. doi https://doi.org/10.1016/j.aquatox.2014.12.018

33. Lewis C, Ellis RP, Vernon E, Elliot K, Newbatt S, Wilson RW (2016) Ocean acidification increases copper toxicity differentially in two key marine invertebrates with distinct acidbase responses. Scientific Reports 6: 21554. doi 10.1038/srep21554

34. Sussarellu R, Lebreton M, Rouxel J, Akcha F, Rivière G (2018) Copper induces expression and methylation changes of early development genes in Crassostrea gigas embryos.

Aquatic Toxicology 196: 70-78. doi https://doi.org/10.1016/j.aquatox.2018.01.001

35. Pellerin J, Amiard JC (2009) Comparison of bioaccumulation of metals and induction of metallothioneins in two marine bivalves (Mytilus edulis and Mya arenaria). Comparative Biochemistry and Physiology Part C: Toxicology \& Pharmacology 150: 186-195. doi https://doi.org/10.1016/j.cbpc.2009.04.008

36. Marisa I, Matozzo V, Martucci A, Franceschinis E, Brianese N, Marin MG (2018) Bioaccumulation and effects of titanium dioxide nanoparticles and bulk in the clam Ruditapes philippinarum. Marine Environmental Research 136: 179-189. doi https://doi.org/10.1016/j.marenvres.2018.02.012 
37. Vernon EL, Smith JT, Jha AN (2018) Relative comparison of tissue specific bioaccumulation and radiation dose estimation in marine and freshwater bivalve molluscs following exposure to phosphorus-32. Journal of Environmental Radioactivity. doi: 10.1016/j.jenvrad.2018.07.005

38. McDonald JH, Seed R, Koehn RK (1991) Allozymes and morphometric characters of three species of Mytilus in the Northern and Southern Hemispheres. Marine Biology 111: 323333. doi 10.1007/bf01319403

39. Binelli A, Della Torre C, Magni S, Parolini M (2015) Does zebra mussel (Dreissena polymorpha) represent the freshwater counterpart of Mytilus in ecotoxicological studies? A critical review. Environmental Pollution 196: 386-403. doi http://dx.doi.org/10.1016/j.envpol.2014.10.023

40. NOAA (2012) Pollution :Changes Over Time: How NOAA's Mussel Watch Program is Adapting to the Needs of Coastal Communities. In: Lauenstein $\mathrm{G}$ (ed)

41. Achard M, Baudrimont M, Boudou A, Bourdineaud JP (2004) Induction of a multixenobiotic resistance protein (MXR) in the Asiatic clam Corbicula fluminea after heavy metals exposure. Aquatic Toxicology 67, 347-357. doi https://doi.org/10.1016/j.aquatox.2004.01.014

42. Manduzio H, Monsinjon T, Galap C, Leboulenger F, Rocher B (2004) Seasonal variations in antioxidant defences in blue mussels Mytilus edulis collected from a polluted area: major contributions in gills of an inducible isoform of $\mathrm{Cu} / \mathrm{Zn}$-superoxide dismutase and of glutathione S-transferase. Aquatic Toxicology 70: 83-89. doi https://doi.org/10.1016/j.aquatox.2004.07.003

43. Voets J, Redeker ES, Blust R, Bervoets L (2009) Differences in metal sequestration between zebra mussels from clean and polluted field locations. Aquatic Toxicology 93, 5360. doi https://doi.org/10.1016/j.aquatox.2009.03.006

44. Chapman PM (2002) Integrating toxicology and ecology: putting the "eco" into ecotoxicology. Marine Pollution Bulletin 44: 7-15. doi https://doi.org/10.1016/S0025326X(01)00253-3

45. Solomon KR, Sibley $P$ (2002) New concepts in ecological risk assessment: where do we go from here? Marine Pollution Bulletin 44: 279-285. doi https://doi.org/10.1016/S0025326X(01)00252-1

46. Schnug L, Jensen J, Scott-Fordsmand JJ, Leinaas HP (2014) Toxicity of three biocides to springtails and earthworms in a soil multi-species (SMS) test system. Soil Biology and Biochemistry 74: 115-126. doi https://doi.org/10.1016/j.soilbio.2014.03.007

47. Gerić M, Gajski G, Garaj-Vrhovac V (2014) y-H2AX as a biomarker for DNA double-strand breaks in ecotoxicology. Ecotoxicology and Environmental Safety 105: 13-21. doi http://dx.doi.org/10.1016/j.ecoenv.2014.03.035

48. Oommen D, Yiannakis D, Jha AN (2016b) BRCA1 deficiency increases the sensitivity of ovarian cancer cells to auranofin. Mutation Research/Fundamental and Molecular Mechanisms of Mutagenesis 784-785: 8-15. doi https://doi.org/10.1016/j.mrfmmm.2015.11.002

49. Fragkos $M$, Jurvansuu J, Beard $P(2009) H 2 A X$ is required for cell cycle arrest via the p53/p21 pathway. Molecular and cellular biology 29: 2828-2840. doi 10.1128/mcb.01830-08

50. Kuo LJ, Yang LX (2008) Gamma-H2AX - a novel biomarker for DNA double-strand breaks. In vivo (Athens, Greece) 22: 305-309

51. Choi JE, Kim S, Ahn JH, Youn P, Kang JS, Park K, Yi J, Ryu D-Y (2010) Induction of oxidative stress and apoptosis by silver nanoparticles in the liver of adult zebrafish. Aquatic Toxicology 100: 151-159. doi https://doi.org/10.1016/j.aquatox.2009.12.012

52. Pereira S, Camilleri V, Floriani M, Cavalié I, Garnier-Laplace J, Adam-Guillermin C (2012) Genotoxicity of uranium contamination in embryonic zebrafish cells. Aquatic Toxicology 109: 11-16. doi https://doi.org/10.1016/j.aquatox.2011.11.011

53. Pereira S, Cavalie I, Camilleri V, Gilbin R, Adam-Guillermin C (2013) Comparative genotoxicity of aluminium and cadmium in embryonic zebrafish cells. Mutation Research/Genetic Toxicology and Environmental Mutagenesis 750: 19-26. doi https://doi.org/10.1016/j.mrgentox.2012.07.007

54. Gagnaire B, Adam-Guillermin C, Festarini A, Cavalié I, Della-Vedova C, Shultz C, Kim SB, Ikert H, Dubois C, Walsh S, Farrow F, Beaton D, Tan E, Wen K, Stuart M (2017) Effects of 
in situ exposure to tritiated natural environments: A multi-biomarker approach using the fathead minnow, Pimephales promelas. Science of The Total Environment 599-600: 597611. doi https://doi.org/10.1016/j.scitotenv.2017.04.210

55. Paravani EV, Simoniello MF, Poletta GL, Zolessi FR, Casco VH (2018) Cypermethrin: Oxidative stress and genotoxicity in retinal cells of the adult zebrafish. Mutation Research/Genetic Toxicology and Environmental Mutagenesis 826: 25-32. doi https://doi.org/10.1016/j.mrgentox.2017.12.010

56. Dallas LJ, Bean TP, Turner A, Lyons, BP, Jha AN (2016) Exposure to tritiated water at an elevated temperature: genotoxic and transcriptomic effects in marine mussels ( $M$. galloprovincialis). Journal of Environmental Radioactivity 164, 325-336.

57. Nalepa TF, Schloesser DW (1992) Zebra mussels biology, impacts, and control. CRC Press

58. Karatayev AY, Boltovskoy D, Padilla DK, Burlakova LE (2007) The invasive bivalves Dreissena polymorpha and Limnoperna fortunei: parallels, contrasts, potential spread and invasion impacts. Journal of Shellfish Research 26: 205-213. doi 10.2983/07308000(2007)26[205:TIBDPA]2.0.CO;2

59. D'Agata A, Fasulo S, Dallas LJ, Fisher AS, Maisano M, Readman JW, Jha AN (2014) Enhanced toxicity of 'bulk' titanium dioxide compared to 'fresh' and 'aged' nano-TiO2 in marine mussels (Mytilus galloprovincialis). Nanotoxicology 8: 549-558. doi 10.3109/17435390.2013.807446

60. Vincent-Hubert F, Arini A, Gourlay-Francé C (2011) Early genotoxic effects in gill cells and haemocytes of Dreissena polymorpha exposed to cadmium, B[a]P and a combination of $\mathrm{B}[\mathrm{a}] \mathrm{P}$ and $\mathrm{Cd}$. Mutation Research/Genetic Toxicology and Environmental Mutagenesis 723: 26-35. doi http://dx.doi.org/10.1016/j.mrgentox.2011.03.008

61. Strober W (2001) Trypan blue exclusion test of cell viability. Current protocols in immunology / edited by John E Coligan [et al] Appendix 3: Appendix 3B. doi 10.1002/0471142735.ima03bs21

62. Jha AN, Dogra Y, Turner A, Millward GE (2005) Impact of low doses of tritium on the marine mussel, Mytilus edulis: Genotoxic effects and tissue-specific bioconcentration. Mutation Research/Genetic Toxicology and Environmental Mutagenesis 586: 47-57. doi http://dx.doi.org/10.1016/j.mrgentox.2005.05.008

63. Kumaravel TS, Jha AN (2006) Reliable Comet assay measurements for detecting DNA damage induced by ionising radiation and chemicals. Mutation Research/Genetic Toxicology and Environmental Mutagenesis 605: 7-16. doi http://dx.doi.org/10.1016/j.mrgentox.2006.03.002

64. Venier P, Maron S, Canova S (1997) Detection of micronuclei in gill cells and haemocytes of mussels exposed to benzo[a]pyrene. Mutation Research/Genetic Toxicology and Environmental Mutagenesis 390: 33-44. doi https://doi.org/10.1016/S0165-1218(96)00162$\underline{0}$

65. Muslimovic A, Ismail IH, Gao Y, Hammarsten O (2008) An optimized method for measurement of gamma-H2AX in blood mononuclear and cultured cells. Nat Protocols 3 : 1187-1193

66. Liu M, Tee C, Zeng F, Sherry JP, Dixon B, Bols NC, Duncker BP (2011) Characterization of p53 expression in rainbow trout. Comparative Biochemistry and Physiology Part C: Toxicology \& Pharmacology 154: 326-332. doi https://doi.org/10.1016/j.cbpc.2011.06.018

67. González-Romero R, Rivera-Casas C, Frehlick LJ, Méndez J, Ausió J, Eirín-López JM (2012) Histone H2A (H2A.X and H2A.Z) Variants in Molluscs: Molecular Characterization and Potential Implications For Chromatin Dynamics. PLOS ONE 7: e30006. doi 10.1371/journal.pone.0030006

68. Oommen D, Dodd NJF, Yiannakis D, Moyeed R, Jha AN (2016a) Linking genotoxicity and cytotoxicity with membrane fluidity: A comparative study in ovarian cancer cell lines following exposure to auranofin. Mutation Research/Genetic Toxicology and Environmental Mutagenesis 809: 43-49. doi https://doi.org/10.1016/j.mrgentox.2016.09.003

69. Sarkar A, Bhagat J, Ingole BS, Rao DP, Markad VL (2015) Genotoxicity of cadmium chloride in the marine gastropod Nerita chamaeleon using comet assay and alkaline unwinding assay. Environ Toxicol 30: 177-187. doi 10.1002/tox.21883 
70. Festarini A, Shultz C, Stuart M, Kim SB, Ferreri C (2015) Cellular responses to tritium exposure in rainbow trout: hto- and obt-spiked feed exposure experiments. CNL Nuclear Review 5: 155-172. doi 10.12943/CNR.2015.00059

71. Jha AN, Dogra Y, Turner A, Millward GE (2006) Are low doses of tritium genotoxic to Mytilus edulis? Marine Environmental Research 62, Supplement 1: S297-S300. doi http://dx.doi.org/10.1016/j.marenvres.2006.04.023

72. Al-Subiai SN, Arlt VM, Frickers PE, Readman JW, Stolpe B, Lead JR, Moody AJ, Jha AN (2012) Merging nano-genotoxicology with eco-genotoxicology: An integrated approach to determine interactive genotoxic and sub-lethal toxic effects of $\mathrm{C} 60$ fullerenes and fluoranthene in marine mussels, Mytilus sp. Mutation Research (Genetic Toxicology and Environmental Mutagenesis) 745, 92-103.

73. Di Y, Schroeder DC, Highfield A, Readman JW, Jha AN (2011) Tissue specific expression of p53 and ras genes in response to the environmental genotoxicants Benzo(a)pyrene in marine mussels. Environmental Science and Technology 45, 8974-8981.

74. Faggio C, Tsarpali V, Dailianis S (2018) Mussel digestive gland as a model tissue for assessing xenobiotics: An overview. Science of The Total Environment 636: 220-229. doi https://doi.org/10.1016/j.scitotenv.2018.04.264

75. Jing G, Li Y, Xie L, Zhang R (2006) Metal accumulation and enzyme activities in gills and digestive gland of pearl oyster (Pinctada fucata) exposed to copper. Comparative Biochemistry and Physiology Part C: Toxicology \& Pharmacology 144: 184-190. doi https://doi.org/10.1016/j.cbpc.2006.08.005

76. Martins CDMG, Barcarolli IF, de Menezes EJ, Giacomin MM, Wood CM, Bianchini A (2011) Acute toxicity, accumulation and tissue distribution of copper in the blue crab Callinectes sapidus acclimated to different salinities: In vivo and in vitro studies. Aquatic Toxicology 101: 88-99. doi https://doi.org/10.1016/j.aquatox.2010.09.005

77. Di Salvatore P, Calcagno JA, Ortíz N, Ríos de Molina MdC, Sabatini SE (2013) Effect of seasonality on oxidative stress responses and metal accumulation in soft tissues of Aulacomya atra, a mussel from the South Atlantic Patagonian coast. Marine Environmental Research 92: 244-252. doi https://doi.org/10.1016/j.marenvres.2013.10.004

78. Jorge MB, Lauer MM, Martins CDMG, Bianchini A (2016) Impaired regulation of divalent cations with acute copper exposure in the marine clam Mesodesma mactroides. Comparative Biochemistry and Physiology Part C: Toxicology \& Pharmacology 179: 79-86. doi https://doi.org/10.1016/j.cbpc.2015.09.003

79. Gundacker C (1999) Tissue-specific heavy metal (Cd, Pb, Cu, Zn) deposition in a natural population of the zebra mussel Dreissena polymorpha pallas. Chemosphere 38: 3339-3356. doi http://dx.doi.org/10.1016/S0045-6535(98)00567-0

80. Regoli F (1998) Trace Metals and Antioxidant Enzymes in Gills and Digestive Gland of the Mediterranean Mussel Mytilus galloprovincialis. Archives of Environmental Contamination and Toxicology 34: 48-63. doi 10.1007/s002449900285

81. Marigomez I, Soto M, Cajaraville MP, Angulo E, Giamberini L (2002) Cellular and subcellular distribution of metals in molluscs. Microsc Res Tech. Mar 1;56(5):358-92.

82. Sanders BM, Martin LS, Howe SR, Nelson WG, Hegre ES, Phelps DK (1994) Tissuespecific differences in accumulation of stress proteins in Mytilus edulis exposed to a range of copper concentrations. Toxicology and Applied Pharmacology 125: 206-213. doi http://dx.doi.org/10.1006/taap.1994.1066

83. Zorita I, Bilbao E, Schad A, Cancio I, Soto M, Cajaraville MP (2007) Tissue- and cellspecific expression of metallothionein genes in cadmium- and copper-exposed mussels analyzed by in situ hybridization and RT-PCR. Toxicology and Applied Pharmacology 220: 186-196. doi https://doi.org/10.1016/j.taap.2007.01.003

84. Larsson J, Smolarz K, Świeżak J, Turower M, Czerniawska N, Grahn M (2018) Multi biomarker analysis of pollution effect on resident populations of blue mussels from the Baltic Sea. Aquatic Toxicology 198: 240-256. doi https://doi.org/10.1016/j.aquatox.2018.02.024

85. Kijewski T, Wijsman JWM, Hummel H, Wenne R (2009) Genetic composition of cultured and wild mussels Mytilus from The Netherlands and transfers from Ireland and Great Britain. Aquaculture 287: 292-296. doi https://doi.org/10.1016/j.aquaculture.2008.10.048 
86. Kijewski T, Śmietanka B, Zbawicka M, Gosling E, Hummel H, Wenne R (2011) Distribution of Mytilus taxa in European coastal areas as inferred from molecular markers. Journal of Sea Research 65: 224-234. doi http://dx.doi.org/10.1016/j.seares.2010.10.004

87. Grosell M, Blanchard J, Brix KV, Gerdes R (2007) Physiology is pivotal for interactions between salinity and acute copper toxicity to fish and invertebrates. Aquatic Toxicology 84: 162-172. doi https://doi.org/10.1016/j.aquatox.2007.03.026

88. Welsh PG, Skidmore JF, Spry DJ, Dixon DG, Hodson PV, Hutchinson NJ, Hickie BE (1993) Effect of $\mathrm{pH}$ and Dissolved Organic Carbon on the Toxicity of Copper to Larval Fathead Minnow (Pimephales promelas) in Natural Lake Waters of Low Alkalinity. Canadian Journal of Fisheries and Aquatic Sciences 50: 1356-1362. doi 10.1139/f93-155

89. Erickson RJ, Benoit DA, Mattson VR, Leonard EN, Nelson HP (1996) The effects of water chemistry on the toxicity of copper to fathead minnows. Environmental Toxicology and Chemistry 15: 181-193. doi 10.1002/etc.5620150217

90. Santore RC, Di Toro Dm Fau - Paquin PR, Paquin Pr Fau - Allen HE, Allen He Fau - Meyer JS, Meyer JS (2001) Biotic ligand model of the acute toxicity of metals. 2. Application to acute copper toxicity in freshwater fish and Daphnia. Environ Toxicol Chem. Oct;20(10):2397-402.

91. Ruiz P, Katsumiti A, Nieto JA, Bori J, Jimeno-Romero A, Reip P, Arostegui I, Orbea A, Cajaraville MP (2015) Short-term effects on antioxidant enzymes and long-term genotoxic and carcinogenic potential of $\mathrm{CuO}$ nanoparticles compared to bulk $\mathrm{CuO}$ and ionic copper in mussels Mytilus galloprovincialis. Marine Environmental Research 111: 107-120. doi https://doi.org/10.1016/j.marenvres.2015.07.018

92. Mersch J, Beauvais MN (1997) The micronucleus assay in the zebra mussel, Dreissena polymorpha, to in situ monitor genotoxicity in freshwater environments. Mutation Research/Genetic Toxicology and Environmental Mutagenesis 393: 141-149. doi http://dx.doi.org/10.1016/S1383-5718(97)00099-5

93. Mersch J, Beauvais MN, Nagel P (1996) Induction of micronuclei in haemocytes and gill cells of zebra mussels, Dreissena polymorpha, exposed to clastogens. Mutation Research/Genetic Toxicology 371: 47-55. doi http://dx.doi.org/10.1016/S01651218(96)90093-2

94. Bolognesi C, Buschini A, Branchi E, Carboni P, Furlini M, Martino A, Monteverde M, Poli P, Rossi C (2004) Comet and micronucleus assays in zebra mussel cells for genotoxicity assessment of surface drinking water treated with three different disinfectants. Science of The Total Environment 333: 127-136. doi https://doi.org/10.1016/j.scitotenv.2004.05.018

95. Digilio G, Sforzini S, Cassino C, Robotti E, Oliveri C, Marengo E, Musso D, Osella D, Viarengo A (2016) Haemolymph from Mytilus galloprovincialis: Response to copper and temperature challenges studied by $1 \mathrm{H}-\mathrm{NMR}$ metabonomics. Comparative Biochemistry and Physiology Part C: Toxicology \& Pharmacology. doi http://dx.doi.org/10.1016/j.cbpc.2016.02.003

96. Clayton ME, Steinmann R, Fent K (2000) Different expression patterns of heat shock proteins hsp 60 and hsp 70 in zebra mussels (Dreissena polymorpha) exposed to copper and tributyltin. Aquatic Toxicology 47: 213-226. doi http://dx.doi.org/10.1016/S0166445X(99)00022-3

97. Bouskill NJ, Handy RD, Ford TE, Galloway TS (2006) Differentiating copper and arsenic toxicity using biochemical biomarkers in Asellus aquaticus and Dreissena polymorpha. Ecotoxicology and environmental safety 65: 342-349. doi http://dx.doi.org/10.1016/j.ecoenv.2005.07.027

98. Sabatini SE, Rocchetta I, Nahabedian DE, Luquet CM, Eppis MR, Bianchi L, Ríos de Molina MdC (2011) Oxidative stress and histological alterations produced by dietary copper in the fresh water bivalve Diplodon chilensis. Comparative Biochemistry and Physiology Part C: Toxicology \& Pharmacology 154: 391-398. doi https://doi.org/10.1016/j.cbpc.2011.07.009

99. Sagripanti JL, Goering PL, Lamanna A (1991) Interaction of copper with DNA and antagonism by other metals. Toxicology and Applied Pharmacology 110: 477-485. doi http://dx.doi.org/10.1016/0041-008X(91)90048-J

100. Klobučar GIV, Pavlica M, Erben R, Papeš D (2003) Application of the micronucleus and comet assays to mussel Dreissena polymorpha haemocytes for genotoxicity monitoring of 
freshwater environments. Aquatic Toxicology 64: 15-23. doi https://doi.org/10.1016/S0166445X(03)00009-2

101.Anjos VA, da Silva-Júnior FMR, Souza MM (2014) Cell damage induced by copper: An explant model to study anemone cells Toxicology in Vitro. 28: 365-372. doi https://doi.org/10.1016/j.tiv.2013.11.013

102. Yu Y, Zhu W, Diao H, Zhou C, Chen FF, Yang J (2006) A comparative study of using comet assay and $\mathrm{YH} 2 \mathrm{AX}$ foci formation in the detection of $\mathrm{N}$-methyl-N-nitro-N-nitrosoguanidineinduced DNA damage. Toxicology in vitro : an international journal published in association with BIBRA 20: 959-965. doi 10.1016/j.tiv.2006.01.004

103. Collins AR (2004) The comet assay for DNA damage and repair: principles, applications, and limitations. Mol Biotechnol 26: 249-261. doi 10.1385/mb:26:3:249

104. Collins AR, Oscoz AA, Brunborg G, Gaivao I, Giovannelli L, Kruszewski M, Smith CC, Stetina R (2008) The comet assay: topical issues. Mutagenesis 23: 143-151. doi 10.1093/mutage/gem051

105.Kumaravel TS, Vilhar B, Faux SP, Jha AN (2009) Comet Assay measurements: a perspective. Cell Biology and Toxicology 25: 53-64. doi 10.1007/s10565-007-9043-9

106. Liao W, A McNutt M, Zhu W-G (2009) The Comet assay: A sensitive method for detecting DNA damage in individual cells. Methods. May;48(1):46-53. doi: 10.1016/j.ymeth.2009.02.016.

107. Mustafa SA, Karieb SS, Davies SJ, Jha AN (2015) Assessment of oxidative damage to DNA, transcriptional expression of key genes, lipid peroxidation and histopathological changes in carp Cyprinus carpio L. following exposure to chronic hypoxic and subsequent recovery in normoxic conditions. Mutagenesis 30, 107-116. 


\section{Vernon and Jha : Figure legends and Table Captions}

Figure 1. Overall experimental design: Experiment 1 (EXP1): Determination of Genotoxic responses; Experiment 2 (EXP2): Determination of bioaccumulation of copper $(\mathrm{Cu})$.

Figure 2. Tissue specific accumulation of copper in $M$. galloprovincialis (left) and D. polymorpha (right), microgram per gram of mussel tissue (dry weight) in control and exposed treatment groups. Asterisks $\left({ }^{*},{ }^{* *}\right.$ or $\left.{ }^{* * *}\right)$ are indicative of significant differences $(p<0.05,0.01,0.001)$ from the corresponding control. SD is standard deviation of mean data. $n=9$.

Figure 3. Pearson's correlation analyses of $\mathrm{Cu}$ accumulation in gill tissue. Top to bottom: DNA damage (\% tail DNA), induction of $\mathrm{y}-\mathrm{H} 2 \mathrm{AX}$ foci and micronuclei (MN) formation in $M$. galloprovincialis (left) and $D$. polymorpha (right). $n=9$.

Figure 4. Photomicrographs showing DNA damage, as measured by \% Tail DNA (top) and induction of $\mathrm{y}-\mathrm{H} 2 \mathrm{AX}$-foci (bottom) in gills cells of $D$. polymorpha following a $1 \mathrm{~h}$ exposure to varying $\mathrm{H}_{2} \mathrm{O}_{2}$ concentrations.

Figure 5. Graphs to show (A) DNA damage (Tail \% DNA) and (B) average number of $\mathrm{y}-\mathrm{H} 2 \mathrm{AX}$ foci in $M$. galloprovincialis and $D$. polymorpha gill cells following exposure to varying concentrations of hydrogen peroxide. SD is standard deviation of mean data. Asterisks $\left({ }^{*},{ }^{* *}\right.$ or $\left.{ }^{* * *}\right)$ are indicative of significant differences $(p<0.05,0.01,0.001)$ from the corresponding control. $n=4$.

Figure 6. Genotoxic responses in $M$. galloprovincialis and $D$. polymorpha gill cells following a 10 day exposure to copper ( $\mathrm{Cu}$ ). (A) DNA damage (\% tail DNA), (B) Induction of micronuclei (MN) and (C) induction of $\mathrm{y}-\mathrm{H} 2 \mathrm{AX}$ foci Asterisks $\left({ }^{*},{ }^{* *}\right.$ or $\left.{ }^{* * *}\right)$ are indicative of significant differences $(p<0.05$, $0.01,0.001)$ from the corresponding control. SD is standard deviation of mean data. Images show (left) control cell and (right) damaged cell. $n=9$.

Figure 7. Pearson's correlation analyses. Top to bottom: \% tail DNA and induction of $\mathrm{Y}-\mathrm{H} 2 \mathrm{AX}$ foci; \% tail DNA and induction of $\mathrm{MN}$ and induction of $\mathrm{MN}$ and $\mathrm{y}-\mathrm{H} 2 \mathrm{AX}$ foci in M. galloprovincialis (left) and D. polymorpha (right). $n=9$.

Table 1. Water quality parameters $(\mathrm{pH}$, temperature, salinity and dissolved oxygen [DO], each parameter measured daily $[n=10]$ ) and copper concentrations in water $(\mu g L-1, n=6)$. Data are presented as mean \pm standard deviation (SD). 